\title{
TRADICIJSKI PRIJEVOZ
}

Danijela BIRT

Sveučilište u Zadru

Odjel za etnologiju i kulturnu antropologiju

Ulica dr. F. Tuđmana 24 i, 23000 Zadar

\section{UVOD}

$I^{-1}$ stražujući na području Senjskoga bila i Krivoga Puta u sklopu terenske nastave, tema tradicijskoga prijevoza iz materijalne kulture primorskih Bunjevaca pokazala se zanimljivom i relevantnom za ocrtavanje njihova tradicijskoga načina života te njihova identiteta. Na taj način identifikacija Bunjevaca prema okolnim zajednicama, prvenstveno prema urbanoj sredini, promatra se kroz jedan oblik materijalnoga života. Osim toga, istraživanjem se pokušalo osvrnuti na jedan dio dosad neistraženoga načina života Bunjevaca u ovom kraju, te kako se stanovništvo kroz ovaj karakteristični segment njihova tradicijskoga života razlikuje u odnosu na susjedne zajednice. Posebice su istaknuti elementi koji se iz kazivanja kazivača razabiru, ali koje i sami kazivači prikazuju kao specifične upravo njihovoj lokalnoj i regionalnoj zajednici. ${ }^{1}$ Kroz svoje iskaze sami kazivači neprestano su isticali činjenicu da se njihov način života razlikuje od njima bliskoga urbanog središta Senja. Tradicijski prijevoz i način uporabe prijevoznih sredstava jedan je od važnih oblika njihova privređivanja i to su kroz svoja kazivanja sami na najbolji način potvrdili. Iako je suživot dviju zajednica intenzivan, upravo zbog toga isticanje "naše" prema "njihovo" još više dolazi do izražaja. Pod "tradicijskim" načinima prijevoza podrazumijevam one koji su prethodili industrijalizaciji (npr. izgradnja tvornica u Senju nakon Drugoga svjetskog rata) i modernizaciji (npr. pojava automobila) ovog područja, koje su se intenzivirale naročito od sedamdesetih godina 20. stoljeća i postupno istisnule "stare" načine prijevoza drvenim kolima i teglećim životinjama.

Istraživanje je provedeno na području Krivoga Puta u pripadajućim zaseocima tijekom dvaju navrata. Prvo terensko istraživanje obavljeno je u lipnju 2003. godine u lokalitetima: Alan, Vrtlina, Rupa, Zamalić, Podbilo, Šimerići, Špalji, Cupići, Žuljevići, Francikovac. Sljedeće je započelo krajem svibnja 2004. godine, u lokalitetima: Krivi Put, Veljun, Šojatski Dolac, Mrzli Dol. Šezdesetih godina 20. stoljeća Krivopućani su intenzivno odlazili živjeti u bliža urbana središta, posebice Senj, tako da i danas poneki zimske dane provode kod djece u Senju. Stoga je dio istraživanja proveden u Senju.

Glavne gospodarske grane većine stanovnika Krivoga Puta tijekom 20. stoljeća do danas su poljoprivreda i stočarstvo. U razdoblju ljetnih mjeseci stariji se stanovnici najradije vraćaju u ova područja, prvenstveno zbog odmora i hladnije klime. Mnogi među njima i danas obrađuje zemlju, ali isključivo za svoje potrebe. Danas više ne možemo govoriti o tome kao osnovnom izvoru prihoda, s obzirom da sada na tom području susrećemo samo starije stanovništvo. Odlazak stanovništva povezan je s potragom za lakšim načinom života koji je isključivao rad na zemlji, pa tako i sve što je bilo vezano uz to, primjerice transportna sredstva. ${ }^{2}$ Prili-

Jedna od specifičnosti je način prilagodbe kola, odnosno sama snalažljivost stanovništva koje je prinuđeno, što prirodnim uvjetima što financijskim prilikama, u jedna kola ugraditi nekoliko vrsta materijala (drvo, željezo, guma).

2 Prilikom prvog odlaska na teren koristila sam se Upitnicom Etnološkog atlasa Jugoslavije broj III (teme: 100. Jaram; 101. Konjska oprema; 102. Kola za rad, saone, vlačuga), izrađene koncem pedesetih godina i početkom šezdesetih godina 20. stoljeća za potrebe nekadašnjeg Etnološkog atlasa Jugoslavije Filozofskog fakulteta u Zagrebu. Osim odgovora na pitanja Upitnice, kazivanja su bila prožeta vlastitim iskustvima kazivača, pojedinim zgodama koje su oni vezivali uz ovu temu. Nakon rekognisciranja terena i transkribiranja kazivanja, prilagodila sam Upitnicu ovom području jer su se tijekom prvog terenskog istraživanja pokazale specifičnosti koje je valjalo naknadno istražiti i provjeriti. 
kom priprema za terensko istraživanje i izradu ovoga rada zanimali su me pristupi istraživanju teme prijevoza i prijevoznih sredstava, te sam napravila uvid u meni dostupnu objavljenu literatura i neobjavljenu građu, točnije Upitnice Etnološkog atlasa.

Iako sustavno istraživanje ovih tema među primorskim Bunjevcima dosad nije bilo obavljeno, uvidom u ispunjene Upitnice Etnološkog atlasa Jugoslavije uspjela sam pronaći podatke za temu 100. Jaram (Fd 241, Krivi Put), temu 101. Konjska oprema (Fd 241, Krivi Put) i temu 102. Kola za rad, saone, vlačuga (Fd 241, Krivi Put). Zapisivač je Slobodan Žikić, a kazivač Milan Krmpotić iz Krivoga Puta. Tema 100. sastoji se od sedamnaest pitanja, tema 101. od četrnaest dok dvadeset jedno pitanje čini temu 102. a svako pitanje ima više ili manje potpitanja. ${ }^{3}$ Unatoč svojoj kratkoći, odgovori daju sliku tadašnjeg stanja na terenu. ${ }^{4}$ Moram naglasiti da sam kroz svoje istraživanje pokušala prikazati prijevoz i njegov razvoj tijekom jednoga vremenskog perioda koliko su mi dopustila sjećanja kazivača; podaci iz Upitnice samo su dopuna i potvrda mojim istraživanjima. Tako sam prilikom izlaganja svojih podataka prikazala i podatke iz upitnice.

Prilikom pretraživanja literature pronašla sam tekstove koji se dotiču teme transporta u nekolicini objavljenih monografija (Kompolje, Poljica, Ivčević Kosa). Monografije su rađene na temelju Osnove za sabiranje i proučavanje grade o narodnom životu Antuna Radića iz 1897. godine i odnose se na druga područja Hrvatske, ali sam odabrala upravo njih zbog blizine području na kojem sam istraživala. Također, pronašla sam nekoliko radova hrvatskih etnologa koji su se bavili ovom temom, ali na drugim područjima Hrvatske. $^{5}$

U monografijama o Kompolju, Ivčević kosi i Poljicima autori su prilikom prikupljanja i obrade podataka dosljedno slijedili upute Radićeve Osnove (Grčević 2000; Hećimović Seselja 1985; Ivanišević 1987). Takav način izlaganja građe prepun je detalja koji su iznošeni na istovjetan način. Dio koji se odnosi na moju temu autori donose pod naslovom Sprave za vožnju i u njemu se detaljno opisuju dijelovi kola, njihova upotreba, saonice te oprema konja i vola, uz dodatak o sredstvima koja su se koristila prilikom prijevoza vode. Premda je pristup istraživanju isti, autori su prikazali građu na različite načine. Tako Ivanišević iznosi svoje zaključke na temelju podataka prikupljenih na terenu, dok druga dva autora donose podatke bez vremenske odrednice, najčešće u "etnografskom prezentu" ili "perfektu".

Pregled narodnog života i običaja Kompolja, sela u Gackoj dolini, donosi nam monografija Jure Grčevića Kompolje izdana 2000. godine, koju je dopunio je i uredio Milan Kranjčević. Ista geografska obilježja i blizina Kompolja i područja Krivoga Puta doprinosi sličnostima u nazivima pojedinih dijelova transportnih sredstava, te njihovim sastavnim dijelovima i općenito izgledu, čime je omogućena i komparacija ovih dvaju područja. Slična usporedba moguća je s podacima iznesenima u monografiji o Ivčević Kosi.

Etnolog Damodar Frlan, u članku iz 1987. godine pod naslovom Transport u okolici Zagreba, daje detaljan pregled transporta i transportnih sredstava. Autor ističe kako je pregled napravljen isključivo u smjeru prikaza tradicionalnih načina transporta bez dodira modernizacije. ${ }^{6}$ Stoga u njegovu radu nije moguće pratiti promjene koje su nastajale kroz određena vremenska razdoblja.

U okviru članka Transport i transportna sredstva iz 1999. godine, Zlatko Mileusnić donosi pregled načina transporta i vrsta transportnih sredstava za područje Općine Pisarovine. Autor raspravlja o utjecaju geografskih te povijesnih prilika koje su uzrokovale određena migracijska kretanja na tom području, kao i o promjenama koje donosi suvremeni način života te ističe i velik utjecaj ukinuća kmetstva i raspada zadruga na razvoj prijevoznih sredstava. Njegov pregled daje potpunu sliku transporta na tom području (prenošenje tereta ljudskom snagom, prijevoz pomoću teglećih životinja (kola, saonice), transport na vodi), geografski potpuno različitom od onoga na kojem žive primorski Bunjevci. No, unatoč tome rad se pokazao korisnim za odabir pristupa izradi ovoga rada.

\footnotetext{
Nažalost, zbog rukopisa neki podaci nisu u potpunosti čitljivi.

Zapisivanje podataka provedeno je šezdesetih godina 20. stoljeća.

Radićev upitnik Osnova za sabiranje i proućavanje grade o narodnom životu iz 1897. godine

Autor je koristio kazivanja isključivo starijih kazivača.
} 
U Hrvatskoj etnografiji, Svagdan i blagdan hrvatskog puka (skupina autora) iz 1998. godine, koja je prvi pokušaj cjelovitog prikaza seljačke kulture Hrvata potkraj 19. i u prvoj polovici 20. stoljeća, tema prijevoza nije obrađena.

U knjizi Lovinački kraj Mile Japunđić donosi pregled života i običaja ličkih Bunjevaca navedenoga kraja. Unatoč činjenici da je obradio velik broj tema iz života ovog stanovništva, ne dotiče se ove teme.

Modernizacija koja je zahvatila ova područja istisnula je domaće životinje poput konja, vola i magarca kao teglećih životinja. Te su promjene najvidljivije oko sedamdesetih godina 20. stoljeća. Prilikom istraživanja na ovom širokom području pokazale su se neke razlike, kao što je upotreba samo određene tegleće životinje - na području Podbila to je konj, a na području Veljuna vol. Jedan od razloga specifični su prirodni uvjeti.

Prilikom analize i obrade dobivenih podataka, pokazale su se neke zanimljive lokalne pojedinosti i specifičnosti koje sam u ovom radu izdvojila.

$\mathrm{Na}$ temelju prikupljenih, etnografskih podataka nastojala sam opisati razvoj načina transporta i pomagala koja se pri tome koriste, te njihovu upotrebu unutar šire zajednice. Specifičnosti koje su se pokazale, primjerice korištenje samo kola s četiri kotača, bile su uvjetovane klimatskim i geografskim faktorima. No, detaljna rekonstrukcija pojedinih sredstava prijevoza bila je moguća nakon analize svih kazivanja, s obzirom da se kazivači nisu uvijek mogli prisjetiti svih dijelova, njihovih naziva, načina upotrebe i izgleda. Prilikom ispitivanja često sam se koristila već postojećim skicama koje su bile korisne jer su se kazivači prisjećali nekih pojedinosti, što bi bez takvih skica bilo manje uspješno. Svi kazivači posjeduju samo dijelove kola, a na terenu su zabilježena svega dva primjera cijelih kola. Dijelovi kola najčešće su rasuti na imanju. ${ }^{7}$

Prikupljeni podaci su od početka 20. stoljeća do današnjih dana, najviše podataka odnosi se na razdoblje od dvadesetih do sedamdesetih godina 20. stoljeća. Na taj način bilo je moguće i komparirati podatke $s$ današnjim načinom života. Ta komparacija ukazala je na dubinu i opseg promjena koje su se dogodile u relativno kratkom vremenskom razdoblju, točnije od sedamdesetih godina 20. stoljeća. Tih su godina pa i kasnije promjene, koje se očituju u novim načinima transporta (primjerice izostanak uporabe teglećih životinja) prema kazivanju pojedinih kazivača, najintenzivnije. Koji je razlog tome, odnosno kako i pod utjecajem kojih prilika je došlo do tih promjena, pitanja su na koja sam pokušala odgovoriti. Također, želim ukazati na sve uzroke promjene načina transporta te uvjetovanost izbora transportnih sredstava i načina života Krivopućana. Nimalo lak život u specifičnim geografskim prilikama te financijska situacija vrlo su važni faktori koji su utjecali na razvoj transporta ${ }^{8}$.

Kako je nepristupačnost ovog kraja definirala oblike transportnih sredstava tako su na to utjecaja imale i financijske prilike stanovnika. Odavno je poznato da je konj predstavljao statusni simbol jedne obitelji koji si je malo ljudi moglo priuštiti. I premda je dolaskom modernijih načina transporta, točnije traktora, konj prividno izgubio to mjesto, stanovnici ovih krajeva i dalje u svojoj svijesti njemu pridaju to mjesto. No, upravo su velik utjecaj na izbor tegleće životinje imale geografske osobitosti ovog kraja.

Na čitavom području Krivoga Puta zabilježila sam pojavljivanje triju životinja koje su služile za transport, a to su konj, vol i magarac. Manji dio stanovništva posjedovao je mule (križanac konja i magarca). Konj je kao tegleća životinja daleko spretniji i lakše se njime upravlja nego s volom, koji je spora životinja prikladna samo na ravnim područjima. Prilikom razgovora $s$ kazivačima najčešće su isticali upravo te činjenice kao objašnjenje zašto se na određenom području koristio konj, a na drugom vol. U Alanu, Podbilu, Rupi, Zamaliću, Vrtlini, Šimerićima, Špaljima, Cupićima, Žuljevićima i Krivom Putu, u brdovitijim krajevima ovog područja, stanovništvo je istovremeno koristilo konja, ali i magarca. Potraga za plodnom zemljom često je lokalno stanovništvo tjerala daleko od kuće, u šumu, tako da su i te prilike uvelike utjecale na odabir tegleće životinje.

U sklopu teksta nalaze se skice kola i ostalih predmeta koje sam sama napravila i obilježila (Sl. 4, Sl. 8, Sl.12).

$8 \quad$ Podaci koje iznosim izvorna su kazivanja kazivača prikupljena na terenu. 
Razloge ove podjele pronalazimo u kazivanju kazivača, neki navode da je razlog tome isključivo teren kao Nada Prpić Terezina iz Krivoga Puta i Milan Krmpotić Zekonja iz Veljuna. Prema riječima Marije Tomljanović Toline iz Krivoga Puta, oni su bliže Liki, a Lika je sva imala volove pa su valjde prema njima tako, jedan od razloga upravo je geografski položaj odnosno blizina Like. Marija Tomljanović Čonina iz Podbila ističe da su se u ovom kraju, misleći pri tome samo na Podbilo, najčešće koristili konji, magarac i mula, dok je za Veljun i okolna sela poznato da koriste volove. Njezino kazivanje potvrđuju i ostali kazivači iz Alana, Podbila, Cupića, Šimerića i Špalja. ${ }^{9}$ Objašnjenje takve raspodjele nije nelogično. Isti kazivači kao razlog tome navode reljefne karakteristike određenoga područja: vol je spora i dosta nespretna životinja tako da mu više odgovara ravan teren.

Premda poneki kazivači povezuju posjedovanje magarca s lošijom imovinskom situacijom i oni priznaju da je ponekad upravo bez njega bilo nemoguće doprijeti do nekih livada koje su bile duboko u šumi. No, one obitelji koje si nisu mogle priuštiti konja imale su samo magarca. Ante Šojat iz Šojatskog Dolca opisuje ovim riječima magarca: To je najkonkretnija životinja bila moga si otidi, metni samarić na nju, s konjem tako nisi moga.

Veljun, Šojatski Dolac, Mrzli Dol i Francikovac područja su na kojima se najviše posjedovao vol. Ta mjesta nalaze se na poprilično ravnom dijelu Velebita i graniče s Likom. Neka kazivanja upravo idu u tom smjeru, odnosno kao razlog što se na ovom području koristi vol za transport ističu blizinu Like. U Lici je glavna tegleća životinja upravo vol. (Grčević 2000:183)

Čini se da ipak ne možemo povući crtu i razgraničiti područja jer postoji dosta primjera onih koji su u Šojatskom Dolcu i Veljunu imali konje i, obratno, u Žuljevićima te Krivome Putu volove. Kao razlog tome kazivači najčešće ističu lakše održavanje konja, ali i veću sposobnost i spretnost te životinje. No, često je upravo bavljenje kirijanjem određivalo koja će se vrsta životinje nalaziti u domaćinstvu. Upravo je primjer Pere Vukelića Mrce iz Vukelića zanimljiv jer prema njegovim riječima djed je posjedovao volove, a tek je njegov otac kupio konje i tada se započeo baviti kirijanjem. Petar Šojat Budić iz Šojatskoga Dolca navodi da je njegov otac još 1935. godine prodao volove i počeo koristiti konje zbog lakšeg održavanja istih, ali i veće sposobnosti životinje. To potvrđuje i kazivanje Ivana Krmpotića Šoparina. Naime, njegovi su roditelji u Veljunu koristili konje, ali nakon ženidbe i dolaska u Šojatski Dolac te nakon što je preuzeo imanje od ženina oca počeo je koristiti volove.

Kao što su parili dijelove kola, često su se pri obavljanju težih poslova susjedi s jednim konjem ili volom udruživali i tako si pomagali. Dok su pojedine obitelji, posebice kirijaške, imale i po nekoliko konja, ostali su najčešće imali samo jednu ili dvije životinje. Izvediv je zaključak da je posjedovanje tegleće životinje definirano ne samo reljefnim karakteristikama pojedinog terena, već uvelike ovisi i o financijskoj situaciji pojedine obitelji. Dakako, takvo stanje određuje i obiteljski posao, kao što je primjerice kirijaški. ${ }^{10}$

\section{DOMAĆE ŽIVOTINJE KAO SREDSTVO PRIJEVOZA}

$\mathrm{V}$ ećina stanovnika Krivoga Puta bavila se poljoprivredom i uzgojem stoke. Danas je moguće pronaći tek nekoliko stanovnika koji se i dalje time bave, no, isključivo radi stvaranja prihoda za vlastito kućanstvo. Kako je nepristupačnost ovog kraja definirala oblike transportnih sredstava tako su na to utjecaja imale i financijske prilike stanovnika. Tri su najzastupljenije tegleće životinje na ovom području bile konj, magarac i vol. Na području Krivoga Puta postojale su zanimljive lokalne razlike kao što je uporaba određene životinje na jednom području (konja ili vola). Velik utjecaj na izbor tegleće životinje imale su geografske osobitosti određenoga kraja.

9 Gašpar Butković Rila, Alan; Ivan Vukelić Mikula, Cupići; Marko Tomljanović Cote, Šmerići; Tome Špalj Cucin, Špalji.

10 Za detaljnije podatke osvrnuti se na poglavlje Kirijanje u nastavku priloga. 
Mica Komadina Maričeva iz Alana prisjeća se da su njezini roditelji držali jednog konja, ali i magarca. Isto spominje i Ivica Vukelić Pop iz Rupe prema čijem su kazivanju ljudi koji su bili u mogućnosti, često imali i konje i magarca. Razlog tome bio je nedostatak zemlje za obradu, pa su ljudi odlazili daleko od kuće, čak u šumu gdje su kosili i zatim sijeno prevozili kući. Nepristupačan teren nije dozvoljavao prijevoz kolima, pa se u tim slučajevima koristio magarac sa samarom. Često su susjedi pomagali jedan drugome posuđujući stoku i zajednički dovozeći bale sijena. Petar Šojat Budić iz Šojatskoga Dolca navodi da je njegov otac još 1935. godine prodao volove i počeo koristiti konje zbog lakšeg održavanja istih, ali i veće sposobnosti životinje. Roditelji Ivana Krmpotića Šoparina su na Veljunu koristili konje, ali nakon ženidbe i dolaska u Šojatski Dolac te preuzimanja imanja od ženina oca i on je počeo koristiti volove. Pero Vukelić Mrco iz Vukelića sjeća se kako je njegov djed držao volove, a kasnije je njegov otac kupio konje i od tada su se započeli baviti kirijanjem. ${ }^{11}$ Obitelji koje su se bavile kirijom uvijek su držale snažnije konje. ${ }^{12}$ Dakle, posjed bilo koje vrste stoke imao je vezu ne samo sa zemljopisnim, već i s novčanim mogućnostima, kao i s oblikom posla kojim su se pojedina kućanstva bavila (izvlačenje drva iz šume, prodaja drva, uzgojem hrane za stoku u vlastitoj proizvodnji i dr.).

Kako su mladi ljudi odlučili napustiti život na selu, tako su stariji bili prisiljeni prodavati konje. Mica Komadina Maričeva iz Alana prisjeća se da su njezini roditelji, nakon što su se ona i sestre udale i odselile u Senj, prodali konje i zadržali samo magarce, a tako su i radile i ostale obitelji u selu. ${ }^{13}$

Kako pojedine obitelji nisu bile u novčanoj mogućnosti imati nekoliko konja, za prijevoz težeg tereta, poput drva, posudili bi još jednog od susjeda i tako su parili konje. Primjer za to su nam kazivanja iz Podbila, Alana, Šojatskoga Dolca i Veljuna. Parenje se dogovaralo usmeno i bilo je uzajamno: ako bi ti netko posudio morao si mu uzvratiti. ${ }^{14}$

Konj se morao održavati. Kada bi konj izgubio potkovu znali bi ljudi reći, osta je bos. ${ }^{15}$ Kako su konji Pere Vukelića Mrce iz Vukelića radili poslove izvlačenje drva i trupaca u šumi nužno je bilo da se potkivaju ili da im se očiste kopita svaka dva mjeseca. Ivica Vukelić Pop iz Rupe napominje da je stavljanje potkove posao koji su mogli obavljati samo kovači koji su imali potreban alat. Isti kazivač navodi da se obično konjima koji nisu obavljali teške poslove poput kirije trebalo mijenjati potkove svakih šest mjeseci, prvenstveno zbog toga što je konjima raslo stopalo. U Krivome Putu radio je jedan kovač i najviše su odlazili upravo kod njega, ali ako bi se što dogodilo u šumi morali su sami znati trenutno popraviti nedostatak. Osim konja, potkivali su se i volovi. Nikola Pripić Nikolčin iz Francikovca kao razlog tome navodi loše, neasfaltirane putove, izrađene od šljunka. ${ }^{16}$

Stoka se kupovala na sajmovima, u Otočcu i Brinju. Osim tih sajmova odlazilo se i nešto dalje, kako naglašava, po teže konje. ${ }^{17}$ Takvi konji kupovali su se za kiriju i za druge teže poslove, a znali su težiti i više od pet stotina kilograma. ${ }^{18}$ Put ih je vodio do Karlovca, Zagreba te čak do Bjelovara, za koji ističu da su na tamošnjem sajmu mogli kupiti najbolje konje. ${ }^{19}$

Osim konja i vola koristio se i magarac, ali nas njegova zastupljenost ne treba začuditi ako poznajemo uvjete u kojima su stanovnici živjeli. Strm teren, ali i činjenica da magarac nije zahtjevna životinja koja ne

\footnotetext{
11 Kazivač je uspio sačuvati jaram, star oko 100 godina, koji je pripadao njegovim precima.

12 Milan Tomljanović Periša iz Zamalića navodi da je njegova obitelj unatoč tome što su se bavili kirijom, držala i magarca i volove. Isto potvrđuje i Pero Vukelić Mrco iz Vukelića.

13 Sedamdesetih godina 20. stoljeća.

14 Marija Tomljanović Čonina, Podbilo; Mica Komadina Marićeva, Alan; Ante Šojat i Ivan Krmpotić Šoparin, Šojatski Dolac; Ivica Kristić Šimeta, Veljun.

15 Mica Komadina Marićeva iz Alana.

16 Lokalno stanovništvo ih naziva bijelim putevima.

17 Marija Tomljanović Čnina iz Podbila i Marko Pavelić Mijatin iz Žuljevića.

18 Marko Pavelić Mijatin, Žuljevići.

19 Marko Pavelić Mijatin, Žuljevići; Pero Vukelić Mrco, Vukelići; Ivica Vukelić Pop, Rupa.
} 
traži puno hrane i brige, kao konj ili vol, omogućila je njegovu široku rasprostranjenost. Držanje magarca bilo je znak slabijega imovinskog stanja. Stanovnici Podbila su najviše koristili magarce i zbog neprohodnih puteva koji su vodili do njihovih košanica (livada).

No, magarac je bio spretna životinja kad je riječ o prevoženju lakšeg tereta, te se često ističe kako je jednostavnije bilo nasamariti magarca: ${ }^{20}$ magarac je najkonkretnija životinja moga si otiđi metni na samarić, na konja tako nisi moga. Osim magarca koristila se često i mula, životinja slična magarcu upravo po svojoj spretnosti. Tako je bilo sve do Drugoga svjetskog rata kada sve više u upotrebu dolaze modernija pomagala, traktor. Od šezdesetih godina kada započinju veća iseljavanja mladih s ovog područja zamjetan je pad broja stoke, ali sve veći broj lakše stoke, primjerice magaraca. Roditelji koji su ostajali na selu nisu više radili teže poslove, postalo je nepotrebno posjedovati toliko stoke. Marko Tomljanović Kanada iz Žuljevi-

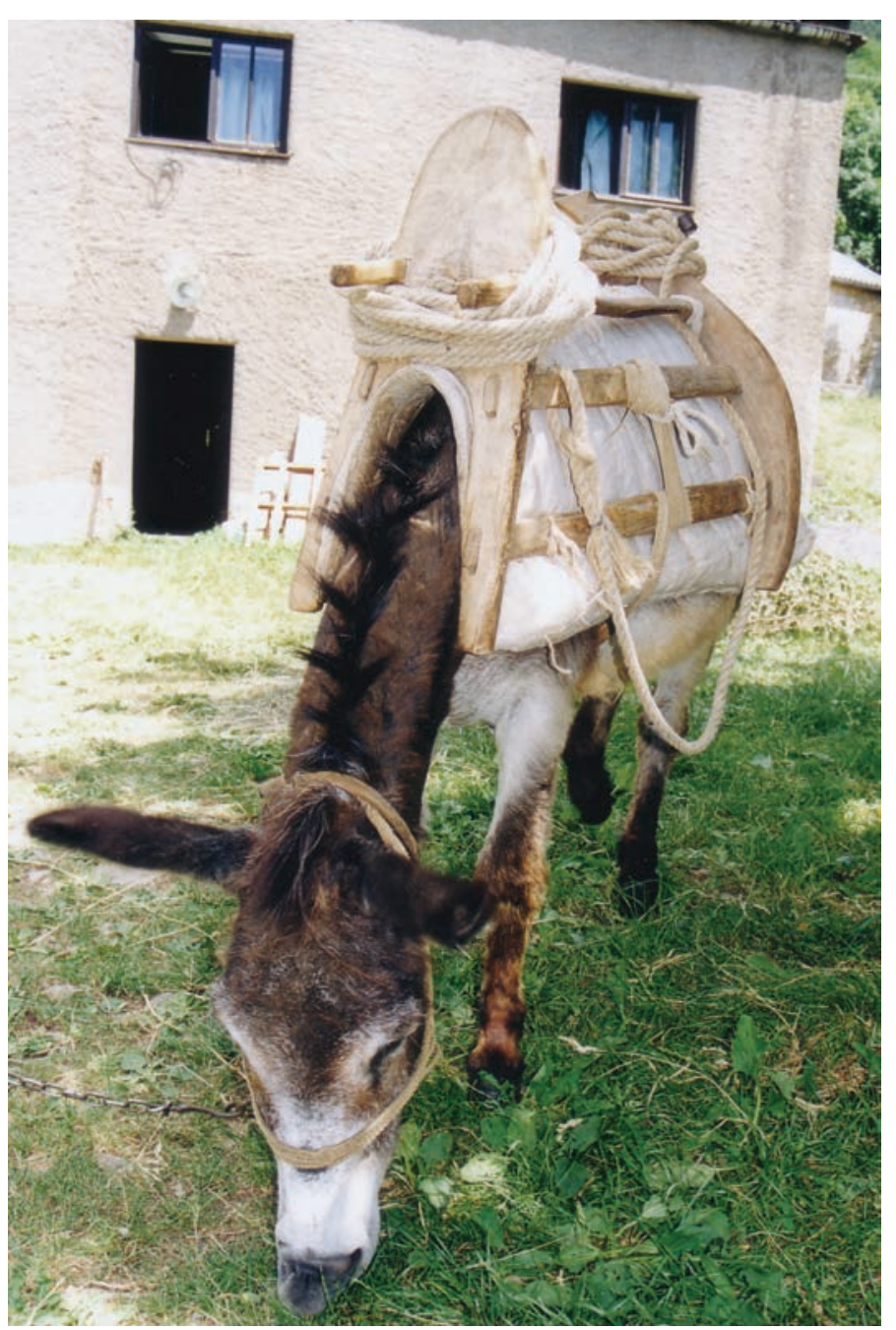

Slike 1: Magarac sa samarom, vlasnike Milan Tomljanović Kanada, Žuljevići; snimio Augustin Perić, lipanj 2003. ća jedini i danas ima magarca, te ga koristi za svoje potrebe, ali je životinja danas više turistička atrakcija, nego tegleća životinja (sl. 1). Ivica Vukelić Pop iz Rupe do prije dvije godine posjedovao je dva konja, ali ne za rad već zbog ljubavi prema životinjama koje su njegovoj obitelji služile godinama. Na području Veljuna i Francikovca još i danas mnogi drže stoku, najčešće krave, koje se nikada nisu koristile za tegljenje već za dobivanje mlijeka i sira.

Tijekom sedamdesetih godina 20. stoljeća, kada sve više dolaze u uporabu traktori, povećala se učinkovitost proizvodnje i olakšao rad, tako da se izgubila svrha posjedovanja teglećih životinja te od tada na krivoputskome području nalazimo sve manje i manje vučnih životinja. Milan Krmpotić Zekonja iz Veljuna koristio je volove posljednji put prije osam, devet godina, samim time i drvena kola čije je dijelove izradio još njegov djed. ${ }^{21}$ Nakon iseljavanja stanovništva, većinom nakon Drugoga svjetskog rata, rijetki su oni koji se bave poljoprivredom i stočarstvom na ovom području već se orijentiraju na druge izvore prihoda (rad u tvornici).22

20 Ovaj izraz koristio je Tome Prpić Marojica iz Mrzloga Dola, a označava stavljanje samara na magarca.

21 Pojedine dijelove drvenih kola uspjela sam fotografirati. Pored njih nalazi se traktor i moderna prikolica, prizor koji povezuje prošlost i sadašnjost.

22 Prema Ivici Vukeliću Popu iz Rupe modernizacija dolazi kasno, već kad su ljudi započeli odlaziti izvan ovog kraja, posebice u Njemačku. 


\section{MODERNIZACIJA PRIJEVOZA}

$\mathrm{K}^{\mathrm{s}}$ ao transportno sredstvo stanovnici Krivoga Puta najčešće su koristili zaprežna kola, a za prijevoz tereta uz pomoć magarca izrađivali su se samari. Prilikom analize dobivene građe pokazale su se neke specifičnosti vezane uz transportna sredstva za ovo područje, koje će poslužiti za daljnje radove na ovu temu. Zbog karakterističnosti terena koristila su se kola s četiri kotača, dok kola s dva kotača nisu pronašla svoju primjenu. Kazivači iz Vukelića, Žuljevića, Veljuna i Francikovca spominju naziv zaprežna kola, ${ }^{23}$ dok kazivači iz Krivoga Puta, Šojatskoga Dolca, Veljuna te Mrzloga Dola koriste naziv drvena kola. U ostalim selima zabilježen je samo naziv kola. ${ }^{24}$ Marija Tomljanović Tolina iz Krivoga Puta, Milan Krmpotić Zekonja, Ivica Kristić Šimeta iz Veljuna i Nikola Prpić Nikolčin iz Francikovca koriste i naziv željezna kola. Razlog tome je taj što su se cijela kola, odnosno njezini drveni dijelovi okovali željezom što je obično radio kovač. Nakon Drugoga svjetskog rata, točnije sedamdesetih godina prema kazivanjima iz Krivoga Puta, Mrzloga Dola, Šojatskoga Dolca, Veljuna te Vukelića dolazi do "modernizacije" kola, odnosno, umjesto lako potrošnih drvenih kotača u širu upotrebu dolaze gumeni kotači. ${ }^{25}$ Nikola Prpić Nikolčin iz Francikovca ističe da do primjene gumenoga kotača dolazi nešto ranije, šezdesetih godina, dok Pero Vukelić Mrco iz Vukelića te promjene vezuje uz osamdesete godine 20. stoljeća. Kako navode Tomo Prpić Marojica iz Mrzloga Dola i Nikola Prpić Nikolčin iz Francikovca promjena je obično podrazumijevala i izradu novih kola jer stara najčešće nisu odgovarala novim kotačima. Taj oblik kola dobiva naziv gumena kola ili gumenjak. Kako stanovnici još uvijek nisu bili u mogućnosti posjedovati traktore i ova kola vukli su konji, odnosno volovi. ${ }^{26}$ Drveni dijelovi polako su izlazili iz uporabe i zbog težeg održavanja, a sve veći udio imalo je željezo (sl. 2).

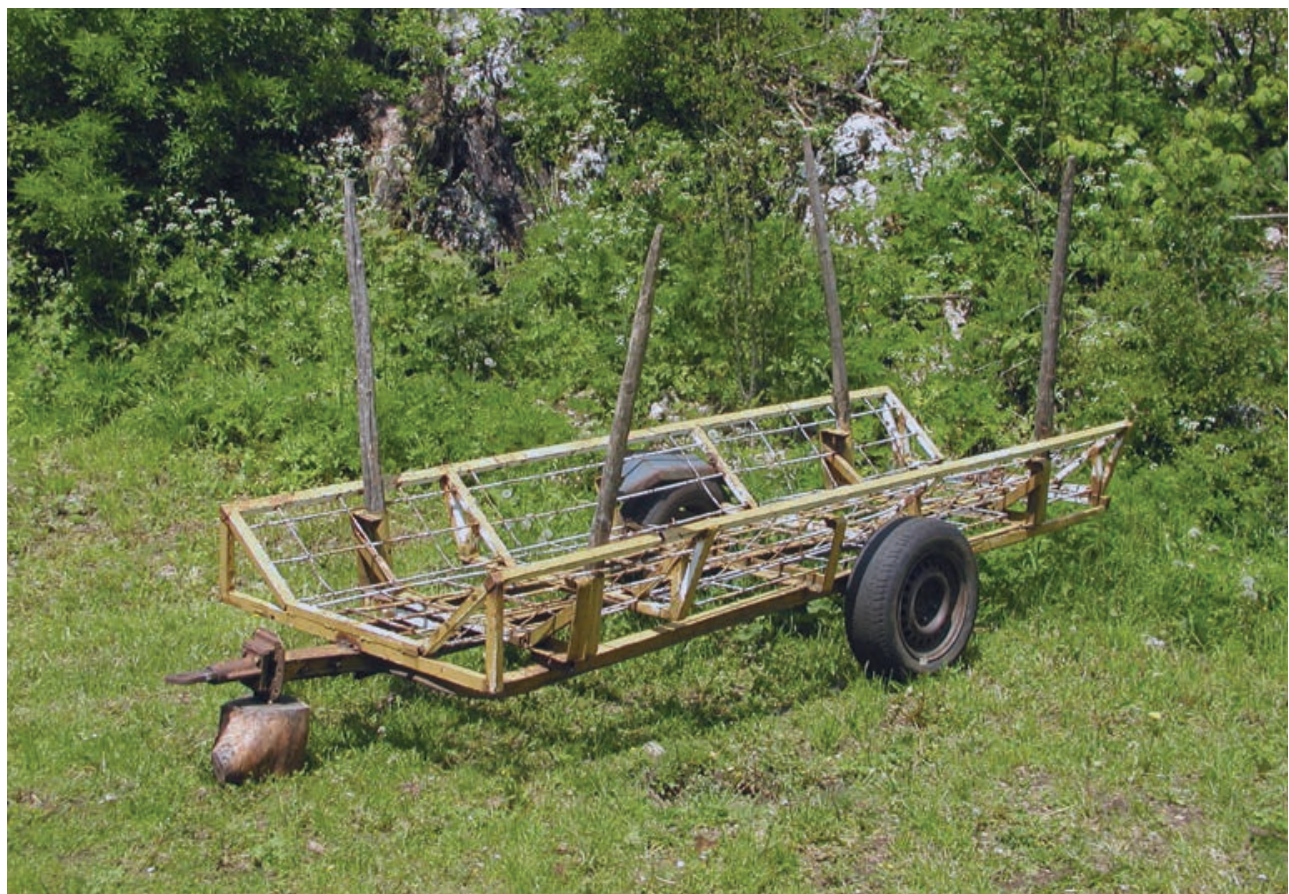

Slika 2: Slika kola sastavljenih od željeza i drveta, Mrąli dol; snimila Jasmina Jurković, svibanj 2004.

23 Pero Vukelić Mrco,Vukelići; Marko Pavelić Mijatin, Žuljevići; Luka Krmpotić Brnde, Veljun; Nikola Prpić Nikolčin, Francikovac.

24 Nada Prpić Terezina i Zlata Tomljanović Pešina, Krivi Put; Ante Šojat, Šojatski Dolac; Luka Krmpotić Brnde, Veljun, Tome Prpić Marojica, Mrzli Dol.

25 Tome Prpića Marojica, Mrzli Dol; Nada Prpić Terezina, Krivi Put; Ante Šojat, Šojatski Dolac; Milan Krmpotić Zekonja i Ivica Kristić Simeta, Veljuna.

26 Imala sam prilike kod Milana Krmpotića Zekonje iz Veljuna vidjeti izgled današnjih kola. 
Tako danas Milan Krmpotić Zekonja iz Veljuna svoje sijeno prevozi u kolima potpuno napravljenim od željeza, ali i uz pomoć traktora koji vuče kola (sl. 3).

Željezom se okivalo isključivo zbog zaštite drvenih dijelova, ali se time i povećavala izdržljivost i dugotrajnost kola. Željezne dijelove izrađivao je kovač. Nada Prpić Terezina i Marija Tomljanović Tolina iz Krivoga Puta te Ivana Krmpotić Šoparina iz Šojatskoga Dolca spominju da mnogi stanovnici nisu u mogućnosti imati cijela kola već samo jedan dio kola, prednji ili stražnji, tako da su kao i kod konja parili njihove dijelove. ${ }^{27}$ Marko Pavelić Mijatin iz Žuljevića objašnjava kako je u cijelome Krivome Putu u vrijeme kada je on bio mlad, tridesetih godina 20. stoljeća, kola imalo samo nekoliko kuća, ja i njegovi (misli na obitelj Marka Tomljanovića Cote iz Šimerića), od poštara djed i Puljizi, Čne (Milan Tomljanović Čna, Podbilo) i u Šolićima Murta.

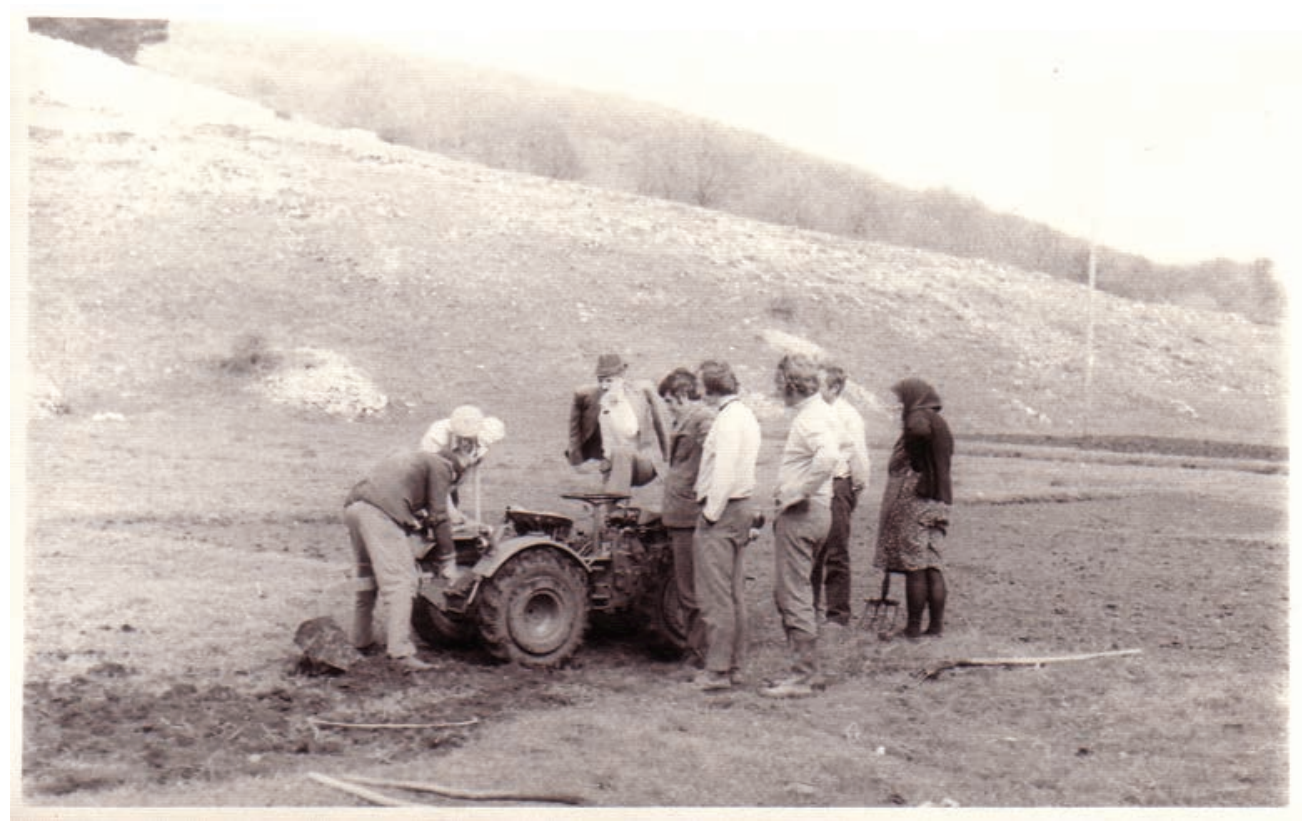

Slika 3: Traktor u Krivome Putu sedamdesetih godina. Iz obiteljskog albuma Zlatka Tomljanovića Peše.

\section{DIJELOVI KOLA}

$I^{2}$ zrada kola zahtijevala je dugogodišnje iskustvo u načinu izrade i izboru materijala. Prema Anti Šojatu iz Šojatskoga Dolca drvo se moralo dobro osušiti tako da se naknadno ne bi rasušilo. Postupak sušenja trajao je i nekoliko godina. Najviše se koristila jasenovina. ${ }^{28}$ Jasen, najtvrđe drvo, najviše se može naći u šumama na području Krivoga Puta kao i javor kojeg spominje samo Ivica Kristić Šimeta. ${ }^{29}$ Premda su je neki kazivači spominjali kao meko drvo za tu namjenu, Tome Prpić Marojica iz Mrzloga Dola ističe da se znala koristiti i bukovina. Nada Prpić Terezina iz Krivoga Puta, i Milan Krmpotić Zekonja iz Veljuna napominju da su se majstori koji su izrađivali drvene dijelove kola nazivali kolari ili tesari prema Tomi Prpiću Marojici iz Mrzloga Dola. Jedan majstor živio je u Francikovcu. Danas je njegov unuk također majstor, ali

$\overline{27}$ Marko Tomljanović Cote iz Šimerića ističe da kako je njegov otac tek poslije rata mogao imati kola, te je tako mnogima u selu pomagao i posuđivao ih.

28 Tomo Prpić Marojica, Mrzli Dol; Nada Prpić Terezina i Mariji Tomljanović Tolina, Krivi Put; Ivica Kristić Šmeta, Veljun; Ante Šojat, Šojatski Dolac; Milan Tomljanović Perǐ̌a, Zamalić; Nikola Prpić Nikolčin, Francikovac.

29 Najčešći je komentar svih kazivača. 
više ne izrađuje kola, već samo drveninu za potrebe svoje kuće. ${ }^{30}$ Iako su postojali izučeni majstori često puta su ljudi sami izrađivali barem drvene dijelove kola kako navodi Ivica Kristić Šimeta iz Veljuna. Marko Pavelić Mijatin iz Žuljevića prisjeća se imena nekih majstora koji su bili vični tom poslu, Milica Cote i Pere Ivčev, obojica iz Krivoga Puta.

Kovača je bilo nekoliko, ali kazivači ističu da je samo jedan živio na području Krivoga Puta. ${ }^{31}$ Ivan Krmpotić Šoparin iz Šojatskoga Dolca, Milan Krmpotić Zekonja iz Veljuna i Zlata Tomljanović Pešina iz Krivoga Puta i Nikola Prpić Nikolčin iz Francikovca napominju da su dvojica živjela na Vratniku. ${ }^{32}$ Danas je taj obrt doslovno nestao kako više nije nalazio svoju primjenu, no prema Marku Paveliću Mijatinu iz Žuljevića iznimka su kovači u Vratniku i Ponikvama koji $i$ danas imaju stare alate $i$ rade na stari način.

Prema kazivanju, željezo koje je kovač koristio za okivanje kola naziva se šinja ili žinja. ${ }^{33}$ Prilikom okivanja kovač je šinju zagrijavao do visokih temperatura kako bi je lakše mogao savinuti, dok bi je za drvene dijelove učvršćivao čavlima. ${ }^{34}$ Cijela su se kola spajala kovačkim vijcima prema Nikoli Prpiću Nikolčinom iz Francikovca (sl. 4).

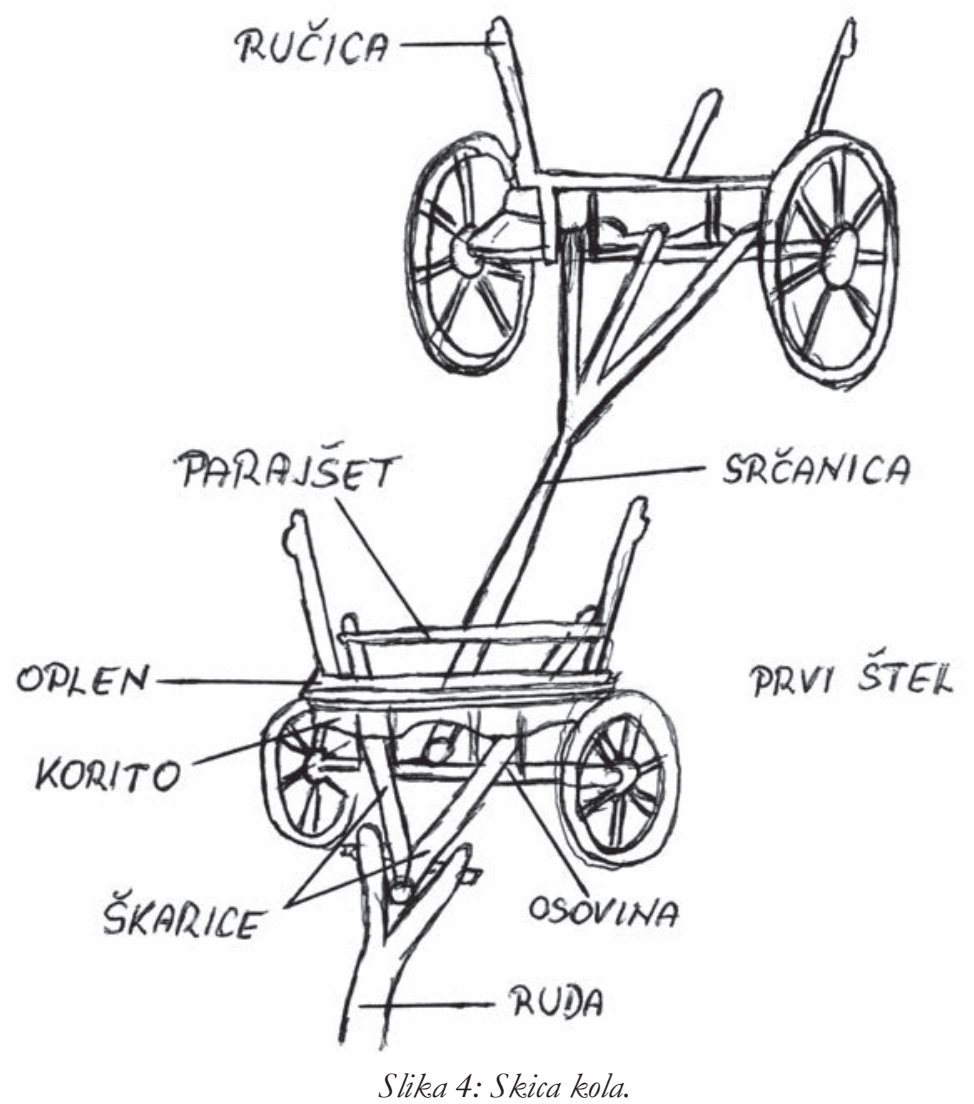

Kola je bilo nužno zaštititi od kiše i zime jer se na taj način njihova trajnost produžavala. ${ }^{35}$ Milan Krmpotić Zekonja iz Veljuna i Milan Tomljanović Periša iz Zamalića napominju da su se kola upravo iz

\footnotetext{
30 To je kazivač Nikola Prpić Nikolčin iz Francikovca.

31 Nada Prpić Terezina i Zlata Tomljanović Pešina, Krivi Put; Ante Šojat i Ivan Krmpotić Šoparin, Šojatski Dolac; Ivica Kristić Simeta, Veljun; Nikola Prpić Nikolčin, Francikovac.

32 Ivan Krmpotić Šoparin iz Šojatskoga Dolca navodi da je jedan živio u Matičima.

33 Žinja prema Marku Paveliću Mijatin iz Žuljevića.

34 Sam postupak okivanja kola teško je rekonstruirati jer kazivanja kazivača koji su tek prisustvovali tome nisu dovoljna, no ipak su neke pojedinosti poznate.

35 Nada Prpić Terezina, Krivi Put.
} 
tog razloga i bojala, ali i zato da bi ljepše izgledala. Vrsta boje bila je stvar osobnoga ukusa. Dok je Milan Krmpotić Zekonja iz Veljuna svoja bojao u plavu boju, Milan Tomljanović Periša iz Zamalića bojao je svoja u zelenu, a željezne dijelove u crnu boju. Boja se obično kupovala u trgovini u Senju ili Krivome Putu. Kola su katkad bila ukrašavana i rezbarijama. ${ }^{36}$

Kola su se mogla razdvojiti na prednji i stražnji dio. Također, mogao se mijenjati oblik ovisno o teretu koji je trebalo prevoziti. Prema kazivanju Nade Prpić Terezine i Marije Tomljanović Toline iz Krivoga Puta naziv za prednji i stražnji dio kola jednostavan je: prvi i zadnji dio. No kazivanje Ivana Tomljanovića Tole iz Krivoga Puta, Nikole Prpića Nikolčinog iz Francikovca i Ivice Vukelića Popa iz Rupe ističu naziv prvi $i$ zadnji štel. Milan Krmpotić Zekonja iz Veljuna koristi naziv prva i zadnja kola. Prema Ivanu Tomljanoviću Toli iz Krivoga Puta i prvi i zadnji štel dijelili su se na donji i gornji dio. Kazivač ističe da je kovač ta dva dijela povezivao pomoću željeznih obruča. Naravno to nije bilo dostatno pa je kovač stavljao veliki željezni klin. ${ }^{37}$ Ante Šojat iz Šojatskoga Dolca napominje da su ti željezni dijelovi imali naziv željezni vezovi. Ivan Tomljanović Tole iz Krivoga Puta spominje da je klin bio dug i do pola metra, promjera četrdeset centimetara. Isti kazivač, ali i Milan Krmpotić Zekonja iz Veljuna navode da su prvi štel činili ovi dijelovi: ruda, vagir, škarice, stolac, ručice, osovina, okretača i oplen. Zadnji štel imao je identične dijelove samo što se na njemu još nalazila vinta. ${ }^{38}$ Srčenica ili srčanica, drvena greda, spajala je prednji i stražnji dio kola. ${ }^{39}$ Razmak između prednjeg i stražnjeg dijela kola, prema kazivanju Pere Vukelića Mrce iz Vukelića, Ivana Tomljanovića Tole iz Krivoga Puta i Milana Krmpotića Zekonja iz Veljuna, nazivao se raspon koji je sezao i do četiri metra ako se prevozilo sijeno. Ako to nije bilo potrebno, dužina kola bila je oko dva do dva i pol metra. ${ }^{40}$ Ono što je omogućavalo rastavljanje kola je srčenica koja je na sebi imala nekoliko škulja. ${ }^{41} \mathrm{Nada}$ Prpić Terezina iz Krivoga Puta, Tomo Prpić Marojica iz Mrzloga Dola, Ivan Tomljanović Tole iz Krivoga Puta i Ivica Vukelić Pop iz Rupe spominju željezni klin koji je izrađivao kovač, a povezivao je srčanicu s prednjim i stražnjim dijelom kola. Prema Ivici Vukeliću Popu iz Rupe taj je klin imao naziv parajšet i dosezao je čak pola metra. Ivica Kristić Šimeta iz Veljuna navodi naziv bolser, za ostala mjesta kazivači navode naziv klin.

Konji su se prilikom vuče na kola spajali pomoću rude i vagira. Ruda koja se koristila pri vuči prema Ivici Tomljanoviću Toli iz Krivoga Puta i Milanu Krmpotiću Zekonji iz Veljuna nazivala se konjska ili tvrda ruda. Ono što je držalo rudu ravnom bila je letva koja je činila jednu stranicu škarica, odnosno parajšet. Škarice su se sastojale od tri letve povezane u obliku trokuta i nalazile su se u donjem dijelu prvih kola. Ruda je prema svima kazivačima bila drvena te na vrhu okovana željezom. Na tom vrhu nalazili su se spustevi, dva lančića kojima je ruda spojena na ajam konja. Dužina rude bila je oko tri metra tako postavljena između dva konja da im nije smetala pri kretanju. Ruda je pomoću željeznoga klina bila spojena za škarice.

Osim rude konji su za kola bili vezani pomoću tri vagira. Vagir je duguljasta drvena gredica duga pola metra, okovana na svojim krajevima željezom (sl. 5). Na njemu su se nalazile dvije ringe, na koje su se spajali lanci ili štranjge koje su dolazile s konjskog ajma. ${ }^{42}$ Ante Šojat iz Šojatskoga Dolca navodi da se vagir mogao raditi i od željeza. Prema Milanu Krmpotiću Zekonji iz Veljuna vagir, koji se nalazio na kolima, zvao se glavni vagir i on je bio trajno učvršćen na kola. Ivan Tomljanović Tole iz Krivoga Puta naziva ovaj

36 Prema kazivanju Milana Tomljanovića Periše iz Zamalića.

37 Tomo Prpić Marojica, Mrzli Dol; Milan Krmpotić Zekonja, Veljun; Ivan Tomljanović Tole, Krivi Put; Nikola Prpić Nikolčin, Francikovac.

38 Kočnica.

39 Srčanica prema kazivanju Tome Špalja Cucinog iz Špalji, Nade Prpić Terezine iz Krivoga Puta. Srčenica prema Mariji i Ivanu Tomljanović Tole i Zlati Tomljanović Pešinoj iz Krivoga Puta.

40 Prema Ivici Kristiću Šimeta iz Veljuna kola su najčešće bila duga tri metra.

41 To je rupa.

42 Ringe ili željezni krugovi. 


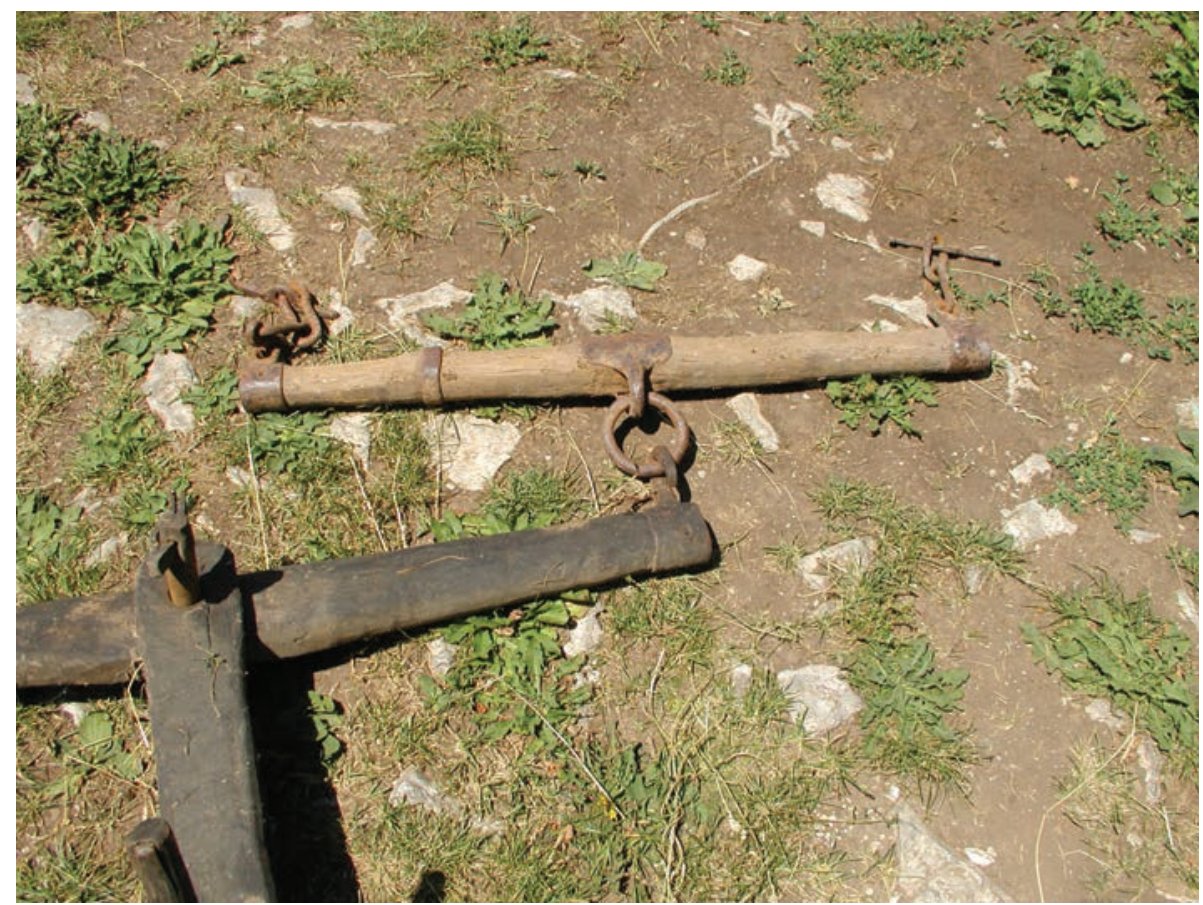

Slika 5: Vagir. Žuljevicí; snimila Jasmina Jurković, lipanj 2003.

vagir velki vagir jer je po svojoj veličini bio puno veći od dva manja konjska vagira. Prema Tomi Prpiću Marojici iz Mrzloga Dola, Milanu Krmpotiću Zekonji iz Veljuna te Ivanu i Mariji Tomljanović Tole iz Krivoga Puta svaki je konj imao još svoj vagir, odnosno to su upravo ti konjski vagiri.

Važan dio kola je okretača (kako je nazivaju u Špaljima, Žuljevićima, Zamaliću, Mrzlome Dolu i Krivome Putu) i/ili okretaljka. To je drvena gredica, debljine desetak centimetara koja omogućava skretanje kola, pri čemu nisu skretali samo kotači nego cijeli prvi dio kola. I na stražnjem dijelu kola nalazila se statična okretača, koja se nije okretala. U nju su i na prvom i zadnjem kraju bile usađene ručice. Okretača je bila duga kao škarice. ${ }^{43}$ Oplen je dio kola na kojem je stajala okretaljka što navode Milan Krmpotić Zekonja iz Veljuna i Ante Šojat iz Šojatskoga Dolca. Prema Ivici Vukeliću Popu iz Rupe, njegova je zadaća bila da povezuje gornji i donji dio kola. On se najčešće izrađivao od željeza. ${ }^{44}$

Prema kazivanju iz Zamalića, Vukelića, Francikovca, Šojatskoga Dolca i Krivoga Puta, iznad osovine nalaze se škarice. ${ }^{45} \mathrm{Na}$ škarice se prema naprijed nadovezuje ruda s vagirom. Škarice su imale oblik trokuta, sastavljene od dva komada drveta. Onaj tko bi sastavljao kola najčešće je pronašao komad drveta koji bi sličio rašljama, a drugi komad drveta bi učvrstio preko njega tako da su zajedno tvorili trokut. Ta izdvojena letva, napominju Milan Krmpotić Zekonja iz Veljuna, Ante Šojat iz Šojatskog Dolca i Ivan Tomljanović Tole iz Krivoga Puta, naziva se parajšet. Njegova zadaća je da ruda stoji ravno.

Drvene letve koje su držale nastavke kola, koji su zadržavali teret, nazivaju se ručice (sl. 6). Milan Krmpotić Zekonja iz Veljuna spominje i naziv stupci. Prema kazivanju Milana Tomljanovića Periša iz Zamalića, Ivice Vukelića Popa iz Rupe, Nade Prpić Terezina i Ivana Tomljanovića Tole iz Krivoga Puta pomoću lanaca ili prema Milanu Tomljanoviću Periši iz Zamalića copuntima učvršćivali su se različiti nastavci za ručice. Ivan Tomljanović Tole iz Krivoga Puta naglašava da su se ti nastavci najčešće stavljali pod određenim

43 Ante Šojat, Šojatski Dolac.

44 Milan Tomljanović Periša iz Zamalića donji dio kola naziva korito, a gornji dio oplen.

45 Milan Tomljanović Periša, Zamalić; Pero Vukelić Mrco, Vukelići; Nikola Prpić Nikolčin, Francikovac; Ante Šojat, Šojatski Dolac; Ivan Tomljanović Tole, Krivi Put. 


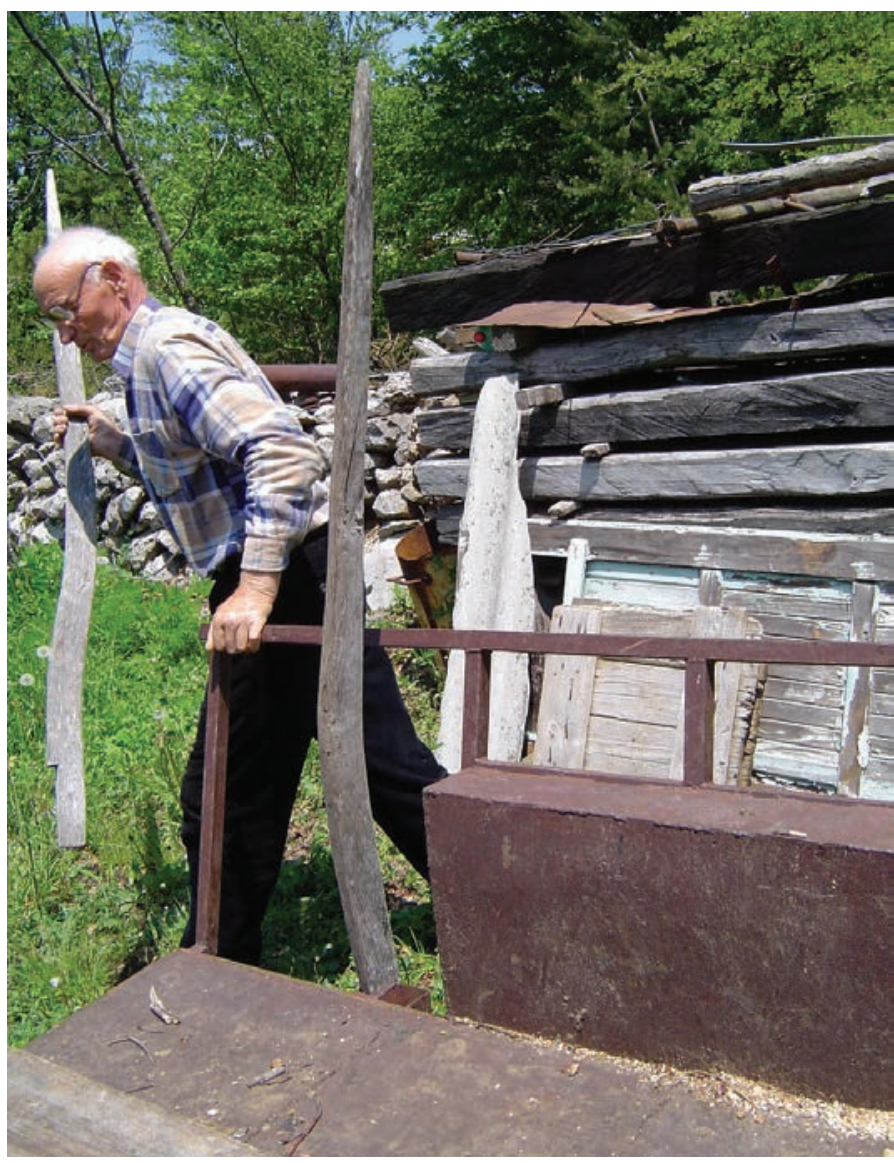

Slika 6: Ručice. Milan Krmpotić Zekonja, Veljun; snimila Danijela Birt, svibanj 2004.

kutom. No to je ovisilo od tereta koji se prevozio. Tomo Prpić Marojica iz Mrzloga Dola, Milan Krmpotić Zekonja, Ivica Kristić Šimeta iz Veljuna te Marija Tomljanović Tolina iz Krivoga Puta napominju da su ručice najčešće visoke do metar, a metar i pol ako se prevozilo sijeno. Nadalje, širina ručica, ističu isti kazivači, bila je od sedam do deset centimetara. Kada se prevozilo sijeno gornji vrhovi ručica obično su se zašiljili. ${ }^{46}$ Tako se moglo složiti više sijena, ali je i voz bio daleko sigurniji. ${ }^{47}$ Kod prijevoza nekog drugog tereta stavljale su se ručice $s$ ravnim vrhovima.

Na stražnjem dijelu kola, točnije na srčanici, nalazi se vinta, napominju kazivači iz Veljuna, Šojatskoga Dolca, Krivoga Puta i Mrzloga Dola (sl. 7). ${ }^{48}$ Čini je komad drveta, zvan kladica u Francikovcu, Veljunu i Krivome Putu, dva lanca i željezni dio. ${ }^{49}$ Željezni je dio vinte, prema Tomislavu Tomljanoviću Talijanu iz Zamalića, izrađivao kovač te je imao oblik šarafa. Prema Ivanu Tomljanoviću Toli iz Krivoga Puta kladica se stavljala ispred stražnjih kotača te je lancima bila povezana sa željeznim dijelom vinte koji se nalazio na srčanici. Isti kazivač ističe da je kladica bila šira od kotača. Kada su kola išla pod brijeg koristila se vinta i to tako da se kladica, zavrtanjem željeznog dijela, naslanjala na kotače i time zaustavljala kola. Nadalje, Ivan Tomljanović Tole iz Krivoga Puta napominje da se vinta od svih dijelova kola najčešće morala mijenjati. To se posebno odnosilo na kirijaška kola koja su prevozeći teret do Senja čak nekoliko puta morala mijenjati kladicu. ${ }^{50}$ Marko Pavelić Mijatin iz Žuljevića napominje, sam čovjek, ako je imao "pametne konje" mogao biti otraga na vinti i vintati, dok su konji sami išli.

Važan dio kola svakako su kotači ili točkovi (sl. 8). Točkove spaja drvena gredica, osovina. Ante Šojat iz Šojatskoga Dolca i Ivan Tomljanović Tole iz Krivoga Puta napominju da se osovina stavljala u drveno ležište korito, koje se nalazilo na oplenu. Ante Šojat iz Šojatskoga Dolca i Ivica Kristić Šimeta iz Veljuna ističu da se upotrebom gumenih kotača osovina radila samo od željeza, dok se ranije izrađivala isključivo od drveta. U pravilu su prednji kotači manji od stražnjih, a taj je način olakšavao upravljanje kolima. ${ }^{51}$ Svi

46 Ivica Vukelić Pop, Rupa; Nikola Prpić Nikolčin, Francikovac; Tomo Prpić Marojica, Mrzli Dol; Nada Prpić Terezina, Marija i Ivan Tomljanović Tole, Krivi Put.

47 Kola puna sijena nazivaju se voz sijena.

48 Milan Krmpotić Zekonja i Ivica Kristić Šmeta,Veljun; Ante Šojat, Šojatski Dolac; Ivan Tomljanović Tole, Krivi Put; Tomo Prpić Marojica, Mrzli Dol.

49 Nikola Prpić Nikolčin, Francikovac; Milan Krmpotić Zekonja, Veljun; Ivan Tomljanović Tole, Krivi Put.

50 Ivan Tomljanović Tole, Krivi Put; Milan Tomljanović Periša, Zamalić.

51 Marko Pavelić Mijatin, Žuljevići; Milan Tomljanović Periša, Zamalić; Tomo Prpić Marojica, Mrzli Dol; Milan Krmpotić Zekonja i Ivica Kristić Šmeta,Veljuna; Marija Tomljanović Tole, Krivi Put. 


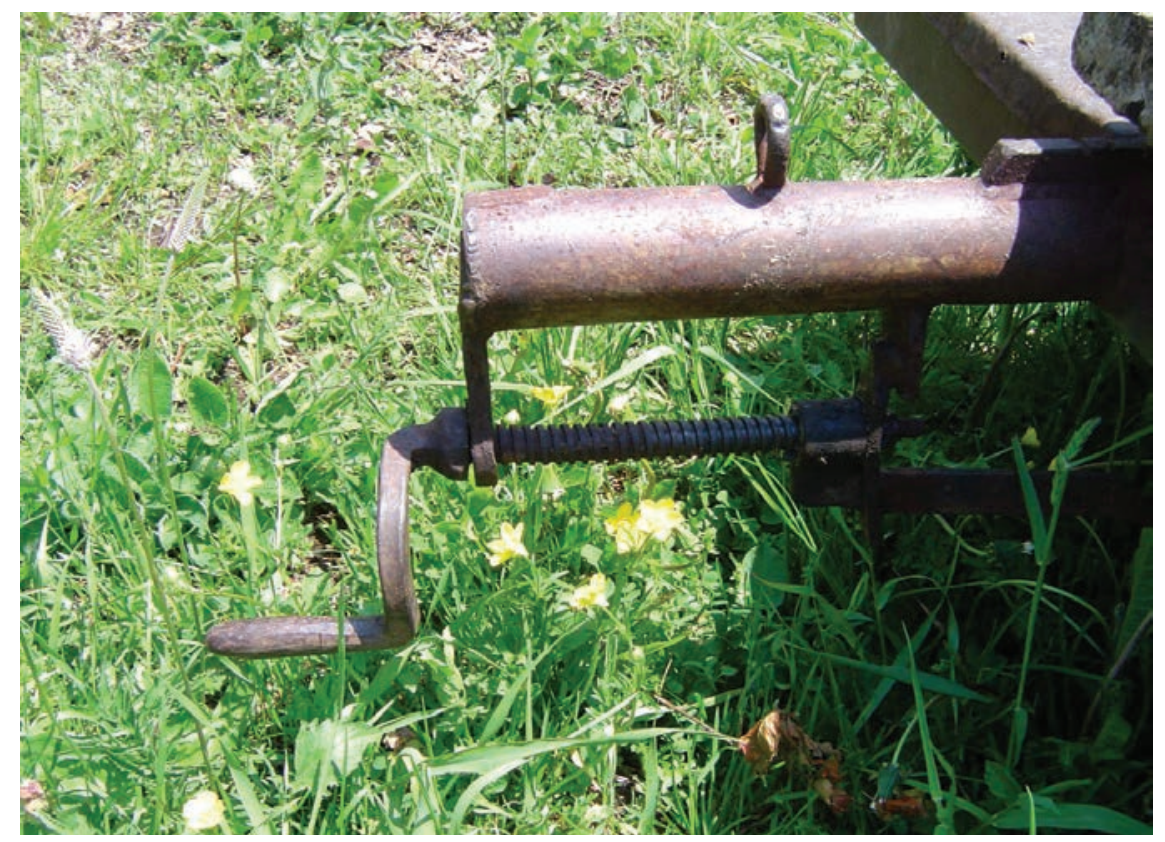

Slika 7: Vinta, Veljun, vlasnik Milan Krmpotić Zekonja; snimila Danijela Birt, lipanj 2004.

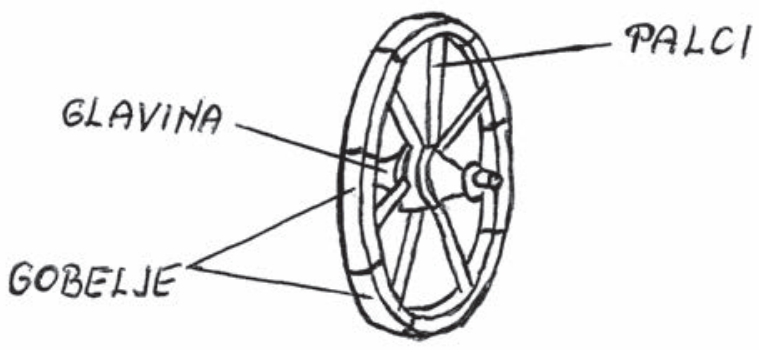

Slika 8: Skica kotača.

kazivači potvrđuju da je postojala samo jedna vrsta kotača. Kotač je također imao drvene i željezne dijelove. Cijeli kotač s vanjske strane okivao se željezom koje su stavljali kovači. Šinja je najčešće bila debljine dva centimetra, kako navodi Tomo Prpić Marojica iz Mrzloga Dola. Gobelje su drveni dijelovi od kojih je kotač bio sastavljen. ${ }^{52}$ U Francikovcu se koristi još i naziv naplataki i poplatak. ${ }^{53}$ Kazivači iz Francikovca, Šimerića i Žuljevića navode da su se gobelje najčešće izrađivale od bukova drveta, upravo iz razloga što je drvo meko i lakše se dalo obraditi. Ivan Tomljanović Tole iz Krivoga Puta i Petar Šojat Budić iz Šojatskoga Dolca ističu da se moglo raditi i od jasena. Glavina i palci najčešće se izrađuju upravo od jasena.

Za gobelje su kolari tražili prirodno krivo drvo ili su ga sami istesali. Kotač se sastavljao od šest ${ }^{54}$ ili tri jednaka gobelja. ${ }^{5}$ U svaku gobelju dolazila su po dva palca, navodi Nikola Prpić Nikolčin iz Francikovca, dok ostali kazivači navode da je u gobelju dolazio po jedan palac.

Središte kotača činila je glavina, potvrđuju kazivači iz Zamalića, Žuljevića, Vukelića, Mrzloga Dola, Šojatskoga Dolca, Krivoga Puta i Veljuna. ${ }^{56}$ Ili, glavčina kako ističe Nikola Prpić Nikolčin iz Francikovca.

\footnotetext{
52 Taj naziv navode svi kazivači.

53 Nikola Prpić Nikolčin, Francikovac.

54 Marko Pavelić Mijatin, Žuljevići, Nada Prpić Terezina i Marija Tomljanović Tolina, Krivi Put.

55 Petar Šojat Budić, Šojatski Dolac.

56 Milan Tomljanović Periša, Zamalić; Marko Pavelić Mijatin, Žuljevići; Pero Vukelić Mrco, Vukelići; Tomo Prpić Marojica, Mrzli Dol; Ante Šojat, Šojatski Dolac; Ivan i Marija Tole Tomljanović; Krivi Put, Ivica Kristić Šimeta, Veljun
} 
Glavina je određenim mjestima okovana željezom s vanjske i unutrašnje strane. Kroz glavinu, kako navode kazivači iz Francikovca, Zamalića, Mrzloga Dola, Šojatskoga Dolca, Krivoga Puta i Veljuna prolazi puš$k a{ }^{57}$ Puška je željezna cijev kroz koju prolazi osovina. Taj se dio kotača podmazivao da kotač ne zahrđa, a i lakše se okretao (sl. 9).$^{58}$ Da kotač ne bi ispao s osovine, stavljao se klin ili špica kako napominju kazivači iz Francikovca, Mrzlog Dola, Šojatskoga Dolca i Krivoga Puta. ${ }^{59}$ Ivica Kristić Šimeta iz Veljuna jedini navodi naziv kajla. Ante Šojat iz Šojatskoga Dolca navodi da je promjer zadnjih kotača iznosio sto dvadeset do sto trideset centimetra. Prema Tomi Prpiću Marojici iz Mrzloga Dola promjer prednjih kotača iznosio je pedeset centimetara, a stražnjih osamdeset centimetara.

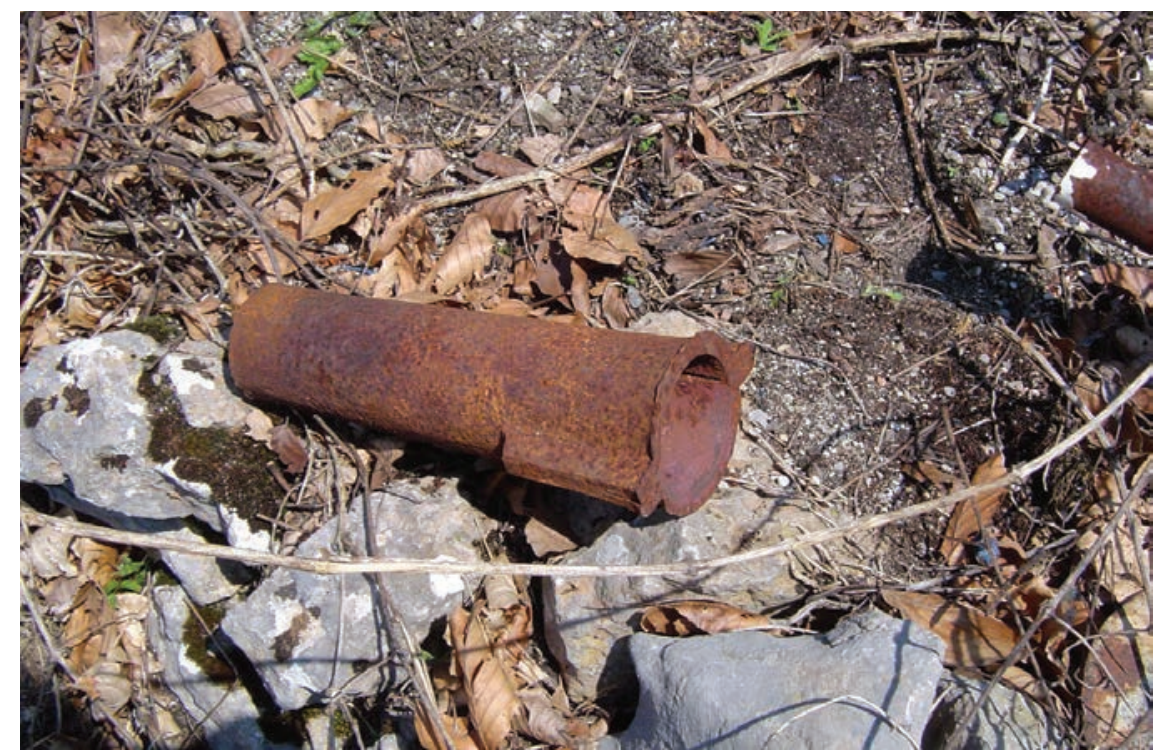

Slikea 9: Puška, Veljun, Milan Krmpotić Zekonja, snimila Danijela Birt, lipanj 2004.

Kako su se vremena mijenjala tako je i u ovim krajevima drvene kotače sve više zamjenjivao gumeni kotač (sl. 10). Dok Nikola Prpić Nikolčin iz Francikovca navodi da je ta promjena započela šezdesetih

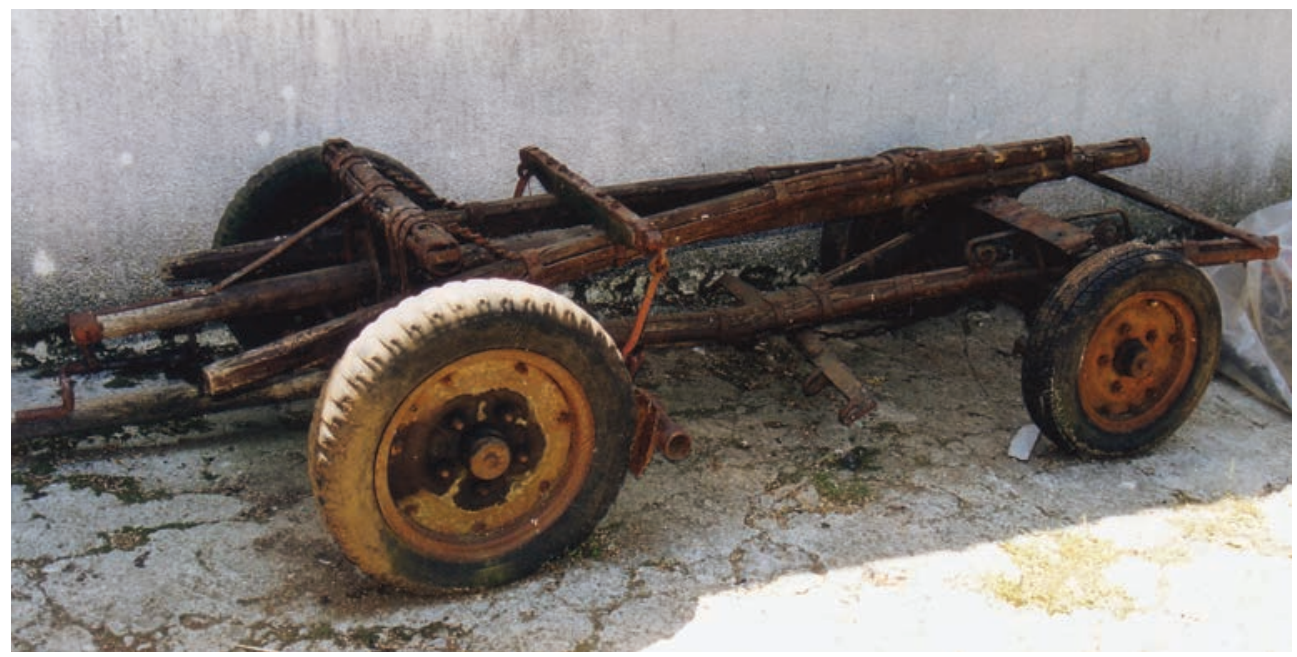

Slike 10: Kola s gumenim kotařma, Francikovac; snimio Augutin Perić, lipanj 2003

57 Nikola Prpić Nikolčin, Francikovca; Marko Tomljanović Periša, Zamalić; Tomo Prpić Marojica, Mrzli Dol; Ante Šojat, Šojatski Dolac; Ivan Tomljanović Tole, Krivi Put, Ivica Kristić Šimeta, Veljun.

58 Tomo Prpić Marojica, Mrzli Dol.

59 Nikola Prpić Nikolčin, Francikovac; Tomo Prpić Marojica, Mrzli Dol; Ante Šojat, Šojatski Dolac; Ivan Tomljanović Tole, Krivi Put. 
godina, Marko Pavelić Mijatin iz Žuljevića ističe da se prijelaz ne može smjestiti u godinu već navodi razdoblje komunizma kao vremenski okvir. Nikola Prpić Nikolčin iz Francikovca napominje da su se drveni kotači često znali rasušiti na suncu, pa su tako bili nekorisni i morali su se često mijenjati, a i unatoč željeznoj šinji brzo bi se potrošili. Gumeni kotači smatrali su se izdržljivijima te su pronašli široku primjenu, a i danas su prisutni.

\section{1. PRIMJENA KOLA}

Tanovnici ovog područja, zbog skromnih financijskih prilika, najčešće nisu mogli imati više vrsta kola: $\checkmark$ kola za sijeno, za gnojivo ili drva. Jedna su kola stoga predelavali, odnosno, prilagođavali za razne potrebe. Kola su mogla imati više namjena: prijevoz sijena, drva, gnojiva i vode, vožnja žita u mlinove. ${ }^{60}$ Ista kola služila su i za odlazak na sajam, a njima su se prevozili i svatovi: Ista kola su služila za teret, za u svadbu ali i za prijevoz mrtvaca. ${ }^{61}$

Prilikom vožnje sijena kola su se rastezala, odnosno rastezala se srčenica. Najčešći naziv koji se koristio za kola na koja je složeno sijenom je voz. ${ }^{62}$ Srčenica je prema kazivanju Pere Vukelića Mrce iz Vukelića i Milana Krmpotića Zekonje iz Veljuna bila duga i do pet metara i na takva se kola uspjelo natovariti i do tisuću kilograma. Kazivači iz Veljuna napominju da su takva kola znala biti duga od tri do četiri metra, te da je količina sijena koja se stavljala ovisila o konfiguraciji terena. ${ }^{63}$ Prema kazivačima na kola se stavljalo deset do petnaest metara sijena, a prilikom toga mijenjale bi se i ručice tako se moglo staviti više sijena. ${ }^{64}$ Na ručice bi se stavljala ograda (okvir), tj. škale za prijevoz sijena. Kako napominju kazivači iz Rupe, Francikovca, Mrzloga Dola, Krivoga Puta i Veljuna, škale su sastavljene od dvije duge drvene gredice poprečno spojene palcima. ${ }^{65}$ Upravo je o duljini škala ovisila i duljina kola. Prema Ivici Kristiću Šimeti iz Veljuna škale su znale biti široke i do dva metra. Milan Krmpotić Zekonja iz Veljuna osim tog naziva koristi i naziv štige, dok Ivan Tomljanović Tole koristi naziv špangele. Škale su lancima vezane za ručice, navode Ivan Kristić Šimeta iz Veljuna, Zlata Tomljanović Pešina i Nada Prpić Terezina iz Krivoga Puta te Tomo Prpić Marojica iz Mrzloga Dola. Kazivači iz Veljuna navode da se donji dio škala stavljao unutar kola, a gornji izvan. ${ }^{66}$ Kako bi se osiguralo da se škale ne šire, odnosno da stoje u jednom položaju, stavljala su se dva drveta također nazvana raspon. ${ }^{67} \mathrm{U}$ Zamaliću i Francikovcu obično su stavljali tek neko drvo tako da sijeno ne propada. ${ }^{68} \mathrm{Na}$ vrh voza sijena stavljalo se drvo zvano žrdina ${ }^{69}$ Prema Luki Krmpotiću Brnde iz Veljuna žrdina se znala odsjeći i u šumi kada se došlo po sijeno tako da se nije morala nositi od kuće. Također se vezala lancima za srčanicu. Tomo Prpić Marojica iz Mrzloga Dola i Zlata Tomljanović Pešina iz Krivoga Puta navode da se na voz stavljalo i granje tako da se sijeno ne rasipa (sl. 11).

$60 \quad$ Najčešće u lička mjesta Prokike i Brlog.

${ }_{61}$ Tomislav Tomljanović Talijan, Zamalić.

62 Nada Prpić Terezina i Zlata Tomljanović Pešina, Krivi Put.

63 Tomo Prpić Marojica, Mrzli Dol; Ivica Kristić Šimeta, Veljun.

${ }^{64}$ Ivica Vukelić Pop, Rupa; Nikola Prpić Nikolčin, Francikovac; Nada Prpić Terezina, Zlata Tomljanović Pešina, Ivan Tomljanović Tole, Krivi Put; Milan Krmpotić Zekonja, Veljun; Tomo Prpić Marojica, Mrzli Dol.

65 Ivica Vukelić Pop, Rupa; Nikola Prpić Nikolčin, Francikovac; Tomo Prpić Marojica, Mrzli Dol, Zlata Tomljanović Pešina, Krivi Put; Ivica Kristić Šimeta, Veljun.

66 Milan Krmpotić Zekonja, Ivica Kristić Šimeta, Veljun.

67 Milan Krmpotić Zekonja, Ivica Kristić Šimeta, Veljun; Nikola Prpić Nikolčin, Francikovac; Tomo Prpić Marojica, Mrzli Dol.

68 Milan Tomljanović Perǐ̌a, Zamalić; Nikola Prpić Nikolčin, Francikovac.

69 Tomo Prpić Marojica, Mrzli Dol; Nada Prpić Terezina, Zlata Tomljanović Pešina, Krivi Put; Milan Krmpotić Zekonja, Ivica Kristić Šimeta, Veljun. 


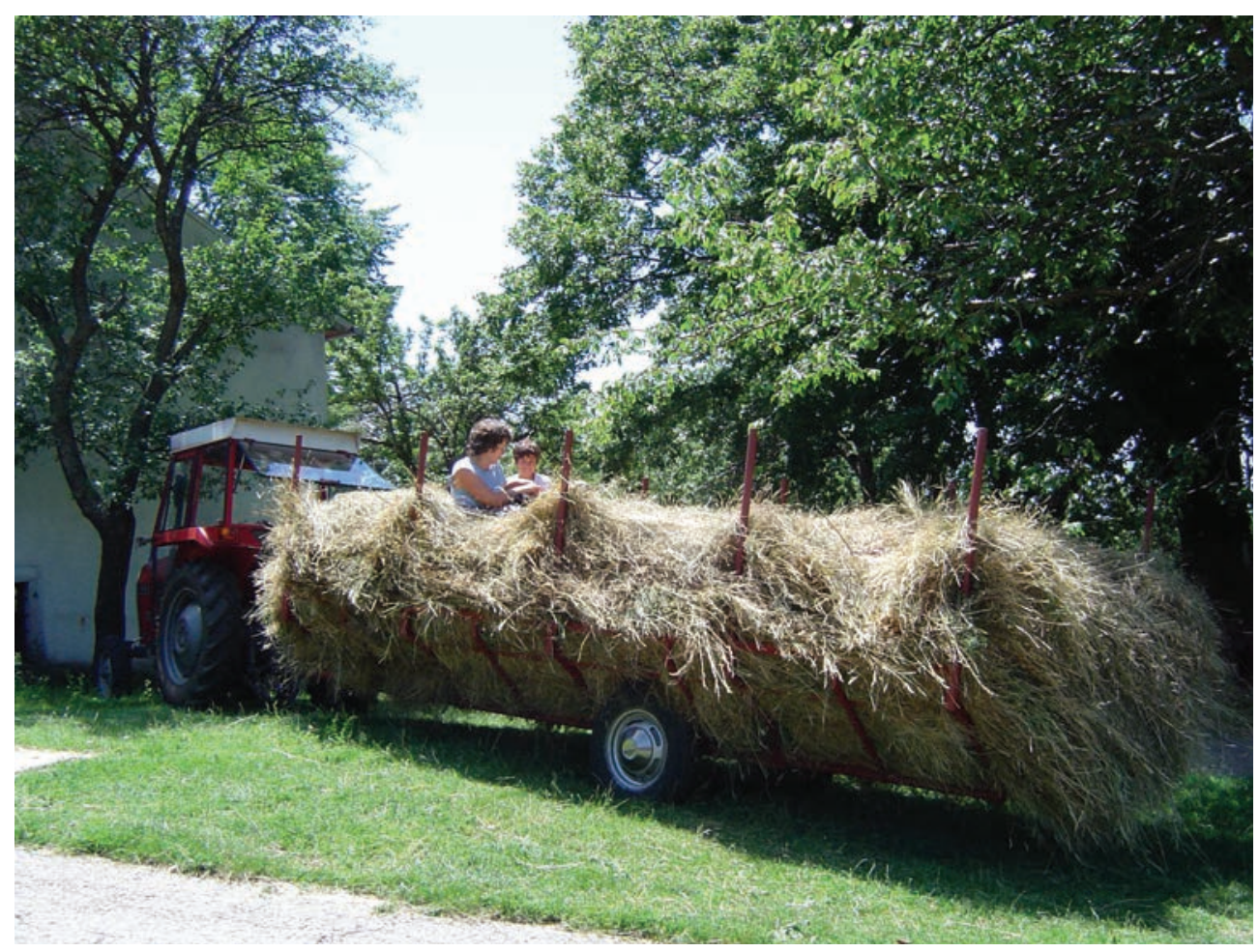

Slika 11: Voz sijena, Francikovac; snimila Danijela Birt, svibanj 2004.

Kada se prevozilo gnojivo na kola se stavljala druga ograda, $\operatorname{lojtra} .^{70}$ Dužina i širina lojtri varirale su, no, to su obično bile dvije ili tri daske široke dvadeset do trideset centimetra i duge dva do dva i pola metra. ${ }^{71}$ S prednje i stražnje strane stavljana su vrata, daske koje su se uglavljivale u utore na lojtrama i na taj su se način mogle brzo ukloniti. Prilikom istovara gnojiva na polju micala su se vrata i tako se lakše istovario teret. $^{72}$

Na konju se često prevozilo žito u mlinove. Mlin u koji su Krivopućani najčešće odlazili bio je vodeni mlin u Klenovnici. ${ }^{73}$ Mica Komadina Maričeva iz Alana vrlo živo se sjeća prvog puta kada je išla sa starijim ženama u mlin, žito smo vozili u mlin u Žrnovnicu dolje prema Novom vinodolskom, dole su bili mlinovi i mi smo ustali u tri ujutro pa sve stavi na magarca i pješice dolje ima 14 kilometara, to je meni bilo veselje (...) išle smo cijelu noć. Taj su posao isključivo radile žene koje su ili kolima ili na magarcu prenosile žito.

Svatovi su također prevoženi kolima; ista kola preuredili bi i uljepšali za tu prigodu. U Francikovcu, Zamaliću i Žuljevićima takva svadbena kola imaju naziv lengeri. ${ }^{74}$ Marko Pavelić Mijatin iz Žuljevića dodaje još i naziv copunti. Ograda se sastavljala od jelovih okruglica, na pod su stavljali daske, dok su sjedala improvizirali stavljanjem obične daske na ogradu. Lengere su, prema kazivanju Nikola Prpić Nikolčin iz Francikovca i Marka Pavelića Mijatin iz Žuljevića, koristili i kada su išli u vašar. ${ }^{75}$

70 Tomo Prpić Marojica, Mrzli Dol; Nada Prpić Terezina, Zlata Tomljanović Pešina, Ivan Tomljanović Tole, Krivi Put; Milan Krmpotić Zekonja, Ivica Kristić Šimeta, Veljun.

71 Tomo Prpić Marojica iz Mrzlog Dola ističe da su lojtre obično široke metar i sedamdeset, dok su visoke oko sedamdeset centimetara.

72 Pero Vukelić Mrco, Vukelići; Milan Tomljanović Periša, Zamalić.

73 Ivan Vukelić Mikula, Cupići.

74 Nikola Prpić Nikolčin, Francikovac; Milan Tomljanović Periša, Zamalić; Marko Pavelić Mijatin, Žuljevići

75 Sajam. Vidi više o toj temi u radu T. Rubić u ovoj monografiji. 


\section{OPREMA KONJA}

prema za uprezanje konja sadržava brojne dijelove: na vrat konja dolazi ham, ajam (u Šimerićima, Žuljevićima, Cupićima, Vukelićima, Francikovcu, Mrzlome Dolu i Krivome Putu) i komot (u Zamaliću, Rupama, Vukelićima i Veljunu) (sl. 12). ${ }^{76}$ Veličinu komota određivala je veličina konjskog vrata, a sastojao se od dva dijela: drvenoga dijela (komotela) opšivenog kožom i kisa tj. zaštitnoga dijela. ${ }^{77}$ Komotela su zakrivljene drvene daske od jasenova drva, opšivene kožom. ${ }^{78}$ Kis se izrađivao od kože i platna koji su se sašili i zatim ispunili s kostreti, kočeti (kozjom dlakom), no ponekad (u nedostatku drugog materijala) i običnom slamom. ${ }^{79}$ U slučaju da se nije mogla nabaviti koža koristila se i jutena vreća. ${ }^{80}$ Kis je štitio konja od ozljeda, a koristio se pretežno kis koji je bio odvojen od drvenoga dijela komota, kako bi se lakše mogao osušiti. To se nazivalo ličkim komotom. ${ }^{81}$ Kožni dijelovi hama najčešće su se ukrašavali rezbarenjem. ${ }^{82}$

Majstori koji su izrađivali komote, ali i ostale dijelove konjske opreme, nazivaju su sotlari. Još sedamdesetih godina 20. stoljeća neki su od njih djelovali na području Krivoga Puta.

$\mathrm{Na}$ glavu konja stavljao se kožni oglav ili ular (Veljun), koji su još činile uzde (vojke) te žvale. Pomoću dva lanca, na koje su se stavljale pule, oglav je spojen s komotom. Pule, okrugle niklovane metalne pločice žute boje služile su kao ukras. Oglavi su bili napravljeni od kože. Dio oglava su i uzde ili vojke koje se vežu na žvale koje su pak napravljene od željeza, a stavljaju se konju u usta. ${ }^{83}$ Žvale bi se koristile kada je trebalo

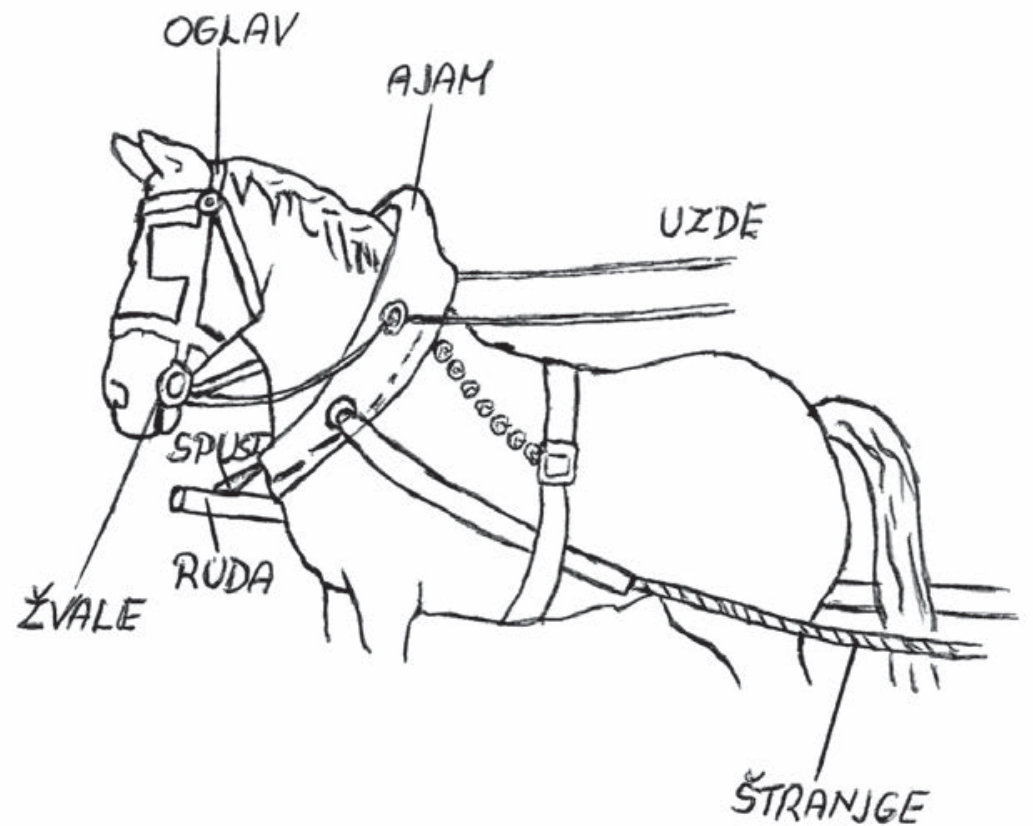

Slika 12: Skica oprema konja

76 Marija i Ivan Tomljanović Tole iz Krivoga Puta nisu se mogli dogovoriti oko naziva. Tako je kazivačica tvrdila da je naziv ajam, dok ju je kazivač ispravljao govoreći da je to komot. Njezina je opaska bila: e al kasnije se tako zvalo naši su to donijeli iz Slavonije (aludirajući na muške stanovnike koji su odlazili na rad ne samo u Slavoniju, već i ostale zemlje bivše Jugoslavije).

77 Ivica Vukelić Pop, Rupa.

78 Navode svi kazivači.

79 Kazivači iz Zamalića, Rupe, Vukelića.

80 Tomo Prpić Marojica iz Mrzloga Dola.

81 Ivica Vukelić Pop, Rupa; Tomislav Tomljanović Talijan, Zamalić. Tomislav Tomljanović Talijan napominje da se takav komot koristio u Lici.

82 Ivica Vukelić Pop, Rupa.

83 Isti kazivač. 


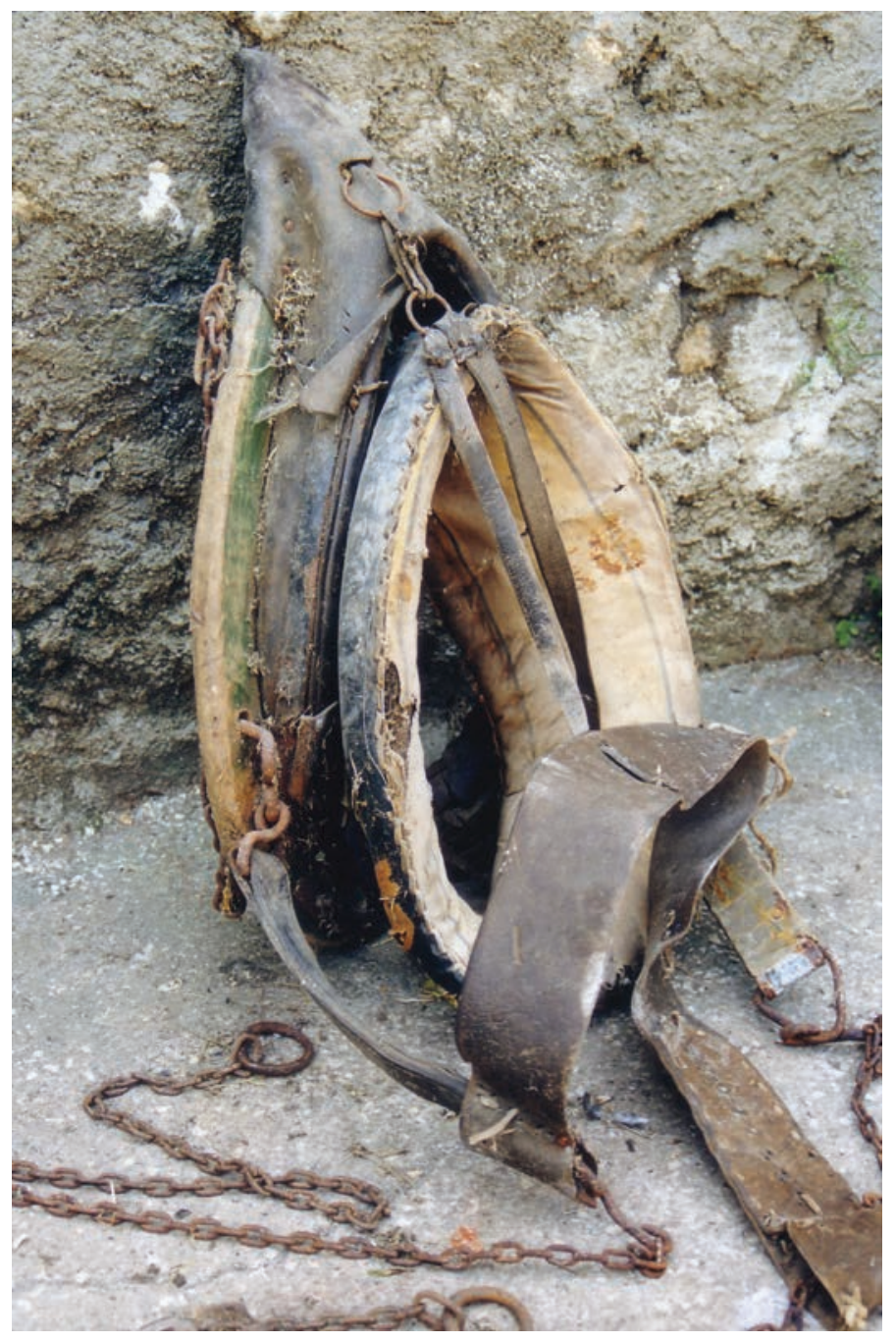

Slika 13: Ajam ili komot, vlasnik. Milan Tomljanović Kanada, Žuljevici; snimila Danijela Birt, lipanj 2003.

upravljati konjem. ${ }^{84}$ Inače, konjima se oči ne bi pokrivale, samo u slučajevima kada se išlo u grad i to ako su konji bili plašljivi.

Dio konjske opreme bio je i šir, kožni kaiš (remen) koji se protezao preko leđa konja, dok je potpregalj ili kolan polazio ispod konjskog trbuha. ${ }^{85}$ Dio sira koji se pružao po konjskom trbuhu naziva se potpregalj. ${ }^{86}$ Potpregalj je osiguravao da se komot i šir ne dižu gore kad se konj kreće. Od sredine komota do sredine sapi konja pruža se dio koji se naziva puška ili stucna. ${ }^{87}$ To je zapravo kožni dio napravljen u obliku tuljca kroz koji se pruža lanac. Taj kožni dio štitio je konja od mogućih ozljeda koje je mogao prouzrokovati lanac. Lanac ili konop ima naziv štrange. ${ }^{88}$ Štrange su napravljene od lanca isključivo zbog toga što su na taj način bile jače. Na kraju štranga stavljale su se ringe što je omogućavalo da se spoje na vagir. Svaki konj je preko svog vagira bio povezan s glavnim vagirom na kolima, kao i s rudom na kola. Na komotu se nalazio spust, lanac koji se vezao na rudu. Ruda je obično dolazila s lijeve strane konja, ako bi se uprezao jedan konj. Vagir je trebao biti udaljen od konjskih nogu i do jedan metar jer bi ga inače ozlijedio. ${ }^{89}$

Da bi zaštitio kopita konja vlasnik ga je odvozio kovaču koji mu je zatim stavljao potkove. Tijekom zimskih mjeseci konji su se manje koristili za poslove, ali je mijenjanje potkova bilo učestalije i zbog rasta kopita.

Važan dio konjske opreme je i bič. Bič se sastojao od dva dijela: drvenoga dijela koji se nazivao korbač i kožnog dijela koji se zvao kandija.${ }^{90}$ Obično se stavljao na komot i tako bi bio na dohvat ruke.

Od vrha komota s obje strane do kaiša na leđima pružali su se ukrasi, okrugle niklovane pule (sl. 13). ${ }^{91}$

\footnotetext{
84 Milana Tomljanovića Mrce, Zamalić.

35 Prema kazivačima iz Krivoga Puta.

86 Ivica Vukelić Pop iz Rupe navodi da se kapa komota nazivala šir.

87 Milan Tomljanović Periša, Zamalić; Milan Krmpotić Zekona, Veljuna.

88 Prema kazivanju Milana Tomljanovića Periše iz Zamalića i Ivice Vukelića Popa iz Rupe.

89 Prema Ivici Vukeliću Popu iz Rupe.

90 Milan Tomljanović Periša, Zamalić; Pero Vukelić, Mrco, Vukelići; Ivica Vukelić Pop, Rupa.

91 Marko Pavelić Mijatin, Žuljevići; Marko Tomljanović, Cote; Milan Tomljanović Periša, Zamalić.
} 


\section{OPREMA VOLA}

snovna oprema volova drveni je jaram (sl. 14). Jaram se sastojao od ravne drvene gredice, koja se također naziva jaram, napravljene od javora te od teljugalteljiga napravljena od drenovine. ${ }^{92} \mathrm{Uz}$ pomoć gužvi teljuge su se dodatno učvršćivale na drvenu gredicu jer drveni klin nije bio dovoljno čvrst. Jaram se gužvom vezao za rudu, a gužve su se izrađivale od bukovih mladica. Obrađivale su se na sljedeći način: na ognjištu dobro upare $i$ istemperale $i$ omotale. ${ }^{93}$ Slično se obrađivalo drenovo drvo koje se koristilo za izradu teljuga. Osim parenja drenova, grana se omatala oko drveta i tako stajala i po par dana. Privor ili klin na jarmu, koji je spajao rudu i jaram, izrađivao se također od javora.

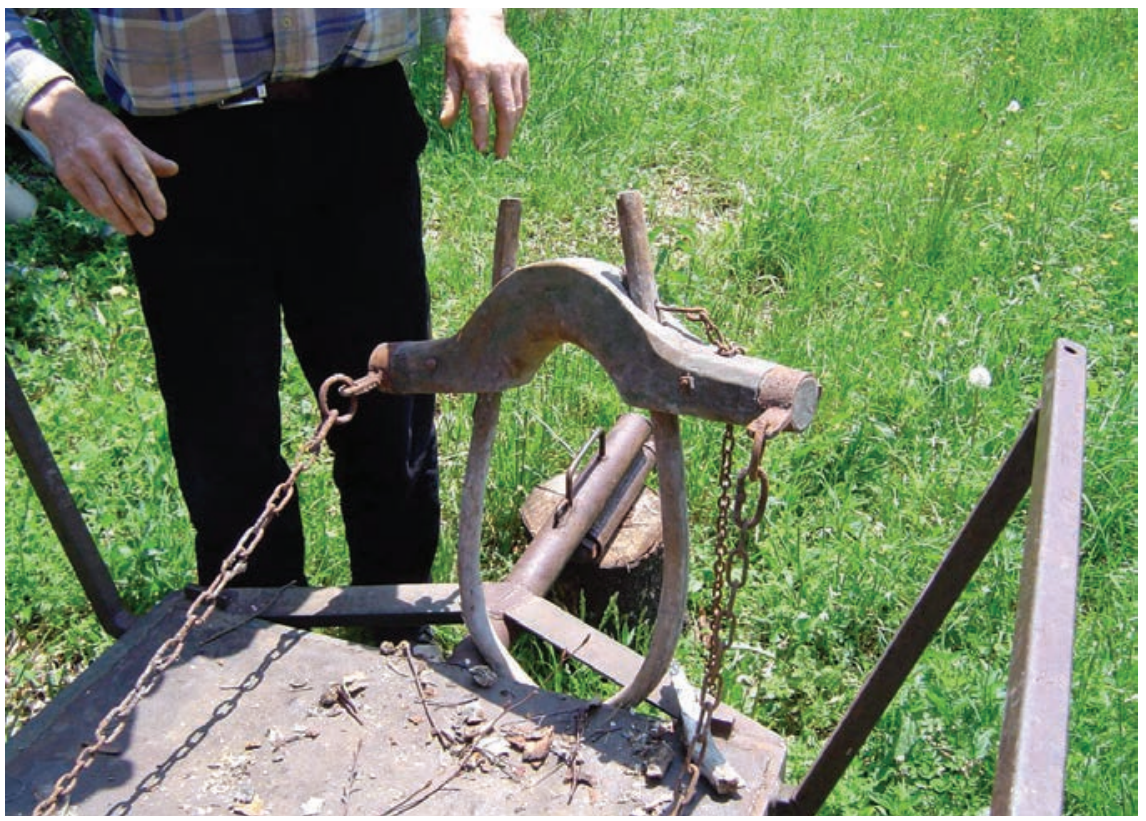

Slika 14: Jaram za jednog vola, vlasnik. Milan Krmpotic Zekonja, izraden sedamdesetih godina 20 st.; snimila Danijela Birt, lipanj 2003.

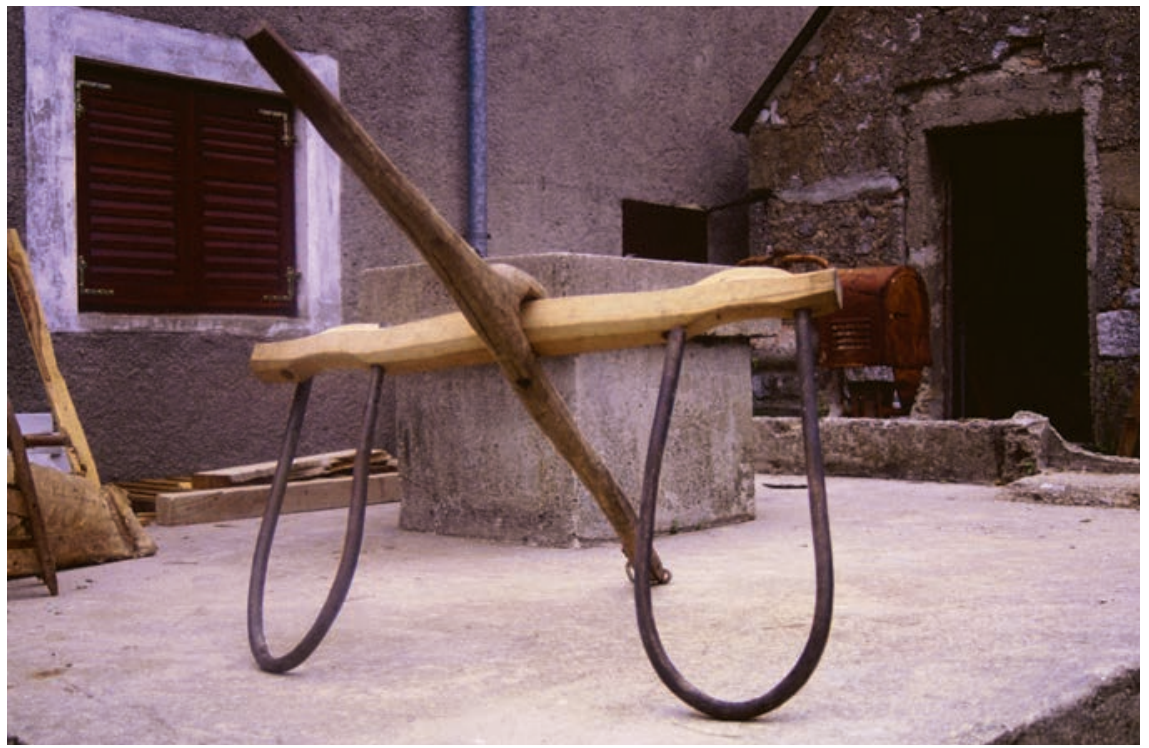

Slika 14a: Jaram za dva vola ${ }^{94}$, Šojatski Dolac; snimio Augustin Peric, lipanj 2005.

\footnotetext{
92 Vrsta drveta.

93 Prema opisu Milana Krmpotića Zekonje iz Veljuna.

94 Za potrebe istraživanja kazivači su improvizirali izgled jarma.
} 


\section{KIRIJANJE}

$\mathrm{D}$ rva su značila posao za većinu stanovnika ovih šumskih krajeva. Pilana je uspješno poslovala do šezdesetih godina prošloga stoljeća. Upravo su muškarci krivoputskoga područja prevozili najviše drva u Senj. Oni koji su se bavili izvlačenjem drva iz šume nazivali su se kirijaši. Kirijom su se najviše bavili stanovnici Alana i njegovih zaselaka. Obitelji koje su se time bavile bile su: u Vukelićima obitelj Pere Vukelića Mrce, u Alanu obitelj Marije Butković Garine, u Zamaliću obitelj Milana Tomljanovića Periše, u Rupi obitelj Ivice Vukelića Popa i u Cupićima obitelj Ivana Vukelića Mikule. Milan Tomljanović Periša iz Zamalića navodi kako je njegova obitelj započela kirijanje 1935. godine, još za vrijeme Kraljevine Jugoslavije.

Posao kirijaša bilo je šlajsanje trupaca iz šume na cestu, no bilo je i onih koji su vozili drva u pilanu. Nakon izvlačenja iz šume drva su se vozila na prodaju u Senj ili u dvije pilane: jednu u blizini Alana, sagrađenu nakon rata, drugu u Krivome Putu kod obitelji Tomljanović. ${ }^{55}$ Zbog nesuglasica, pilana iz Alana premještena je u Krasno, dok je pilana obitelji Tomljanović zapaljena za vrijeme Drugoga svjetskog rata.

Jedan dan u životu kirijaša prema riječima Milana Tomljanovića Periše iz Zamalića izgledao je ovako: bio je to krvnički posao, nisi ni noću imao nikad mira jer dodi doma pa moraš timarit konje onda zimska doba rano se ustaj jer smo mi nekad znali sa saonicama vozit iz šume trupce na pilanu onda se rano ustaj u jedan sat poponoći pa onda dok bi doša gore pa natovari trupce pa na pilanu istovari, kad dođeš kući već je mrak, moraš se presvuć, osušit konje natimarit konje očešljat i onda opet u dva sata kreni ća, celi dan si u šumi. ${ }^{96}$

I ostali stanovnici ovih mjesta odlazili su u šumu po drva za vlastite potrebe za ogrjev. Nakon što bi obradili drva bilo ih je nužno prevesti kući. Drva su se prevozila kolima. U tom slučaju nije se stavljala ograda već samo ručice koje su povezali lancima, a kao pod poslužile su dvije, tri daske. Na kola su se prilikom prijevoza drva stavljale i škale..$^{7}$

\section{SAONICE}

$Z^{i}$ mi, kada se nisu mogla koristiti kola, koristile su se saonice. U svim mjestima Krivoga Puta zabilježen je naziv sane za saonice. Osim tog naziva, zabilježen je i naziv sance. ${ }^{98}$ Kazivači iz Zamalića i Krivoga Puta navode naziv šlite, ali kao naziv za saonice koje su koristili kirijaši ${ }^{99}$ U Žuljevićima, Zamaliću, Rupi, Alanu, Cupićima, Francikovcu, Vukelićima, Krivome Putu, Veljunu, Šojatskome Dolcu saonice su se koristile za prijevoz drva i gnojiva. ${ }^{100}$ No, zbog velikih nanosa snijega saonice se dobrim dijelom nisu mogle koristiti. Saonice se sastoje od plazova, odnosno kriva, dvije drvene letve koje su služile da saonice lako klize po snijegu. Krive su odozdo okovane željezom koje kazivači nazivaju šina. ${ }^{101}$ Katkad su krive bile podmazivane lojem kako bi brže i lakše klizile po snijegu. Krive su, kao i cijele saonice, izrađivane od bukova drveta ili jasena, kao i kod kola. ${ }^{102}$ Bušile su se tako da su u rupe promjera deset centimetara stavljani željezni klinovi. U svaku krivu dolazila su dva klina debljine 40 centimetara. Na te klinove stavljane su drvene daske koje su činile sjedište, odnosno gornji dio saonica. Kao i na kolima, i na saonicama su se nalazile ručice koje

\footnotetext{
95 Tu pilanu posjedovali su rođaci kazivača Ivana i Marije Tomljanović Tole iz Krivoga Puta.

96 Prema riječima Milana Tomljanovića Periše iz Zamalića.

97 Prema kazivanju Tome Prpića Marojice iz Mrzlog Dola i Ivana Tomljanovića Tole iz Krivoga Puta.

98 Marko Pavelić Mijatin, Žuljevići; Pero Vukelić Mrco, Vukelići.

99 Milan Tomljanović Periša, Zamalić; Ivan Tomljanović Tole, Krivi Put.

100 Ivan Krmpotić Šoparin, Šojatski Dolac; Milan Krmpotić Zekonja, Veljun; Nada Prpić Terezina i Ivan Tomljanović Tole, Krivi Put.

${ }^{101}$ Ivan Krmpotić Šoparin, Šojatski Dolac, Milan Krmpotić Zekonja, Veljun; Nada Prpić Terezina i Ivan Tomljanović Tole, Krivi Put.

${ }^{102}$ Ivan Krmpotić Šoparin, Šojatski Dolac.
} 
su pridržavale drveni okvir. Saonice su općenito vrlo nalikovale kolima, tj. imale su iste dijelove. Kazivači napominju da su krive naprijed bile zavinute tako da se lakše moglo prolaziti kroz snijeg. ${ }^{103}$ Zakrivljeno drvo pronalazili bi u šumi ili bi majstor sam izradio drvo zakrivljena oblika. Same krive obično su bile duge metar osamdeset do dva metra i široke oko sedamnaest centimetara. ${ }^{104}$ Često su saonice izrađivali sami vlasnici, a kod kovača bi tek dovozili okivati krive. ${ }^{105} \mathrm{Na}$ prednji dio saonica nadovezivala se ruda na koju se vezao konj ili vol prema Ivanu Krmpotiću Šoparinu iz Šojatskoga Dolca. ${ }^{106}$ Kada bi se prevozila drva maknuli bi drveni okvir napravljen od dasaka koji se koristio kod prijevoza gnojiva na polje.

Kirijaši su koristili nešto snažnije saonice. ${ }^{107}$ Pero Vukelić Mrco iz Vukelića govori da je taj oblik saonica njegov otac donio iz Amerike, tako da je taj oblik saonica u Vukelićima dobio naziv amerikanski sistem, dok su u Zamaliću i Krivome Putu takve saonice zvali šlite. ${ }^{108}$ Šlite su se sastojale od dva dijela, kao i kola, od prednjega i stražnjega. Ta dva dijela nije povezivala srčenica već su bili povezani lancima koji su bili složeni u križ. Pomoću takvih saonica moglo se prijeći i preko suhog dijela, a da ne zastanu, što je bilo jako važno kod izvlačenja i prevoženja trupaca u šumi. Na prednjem se kraju nalazila okretaljka kako bi se lakše manevriralo s teretom. ${ }^{109}$ Šlite su uvijek vukli konji. Saonice za igru bile su improvizirane, izrađivane na domišljate načine, a najčešća zamjena saonicama bile su naćve koje su majke inače koristile za pripremanje kruha.

\section{SAMARI}

$\mathrm{O}$ sim konja i vola, za prijevoz su se najčešće koristili magarac i mula. Za prijevoz tereta uz pomoć magarca izrađivali su se samari (sl. 15), a izrađivali su se i samari za konje. ${ }^{110}$ Kad ne bi bilo dovoljno novca za izradu kola, koristio bi se samar i za konja jer je samar bio dostupniji. Magarac je spretnija životinja za ovo područje te se mogao lakše kretati po vrtačama. Na samarima se prevozio isti teret kao i na kolima: sijeno, gnojivo, drva, voda i sl. Samar se izrađivao od drveta, a izrađivali su ga ljudi koji su se time bavili i stoga su dobivali špicnamet Samardžije. ${ }^{111}$ Samare je izrađivao jedan čovjek koji je živio u Alanu, otac Milana Krmpotića Zekonja iz Veljuna, tako da i njegov sin među posljednjima na Krivome Putu zna izrađivati samare, no danas se time ne bavi jer nema potražnje, kao i jedan čovjek u Francikovcu. ${ }^{112}$ Nadimak Samardija dobila je obitelj čiji su preci radili samare generacijama. Drvo koje se najčešće koristilo za izradu samara bilo je jasenovo ili bukvino. ${ }^{113}$

Dio samara koji dolazi na vrat magarca naziva se glavić, odnosno glava, dok na sapi magarca dolazi križ. ${ }^{114}$ Glavić je najčešće okrugao, dok je križ u obliku križa sastavljen od dvije letve koje su spojene

103 Marko Pavelić Mijatin, Žuljevići; Ivan Krmpotić Šoparin, Šojatski Dolac.

${ }_{104}$ Prema Ivanu Krmpotiću Šoparinu iz Šojatskog Dolca.

${ }^{105}$ Milan Krmpotić Zekonja, Veljun; Ivan Krmpotić Šoparin, Šojatski Dolac.

${ }_{106}$ Milan Krmpotić Zekonja, Veljun; Ivan Krmpotić Šoparin, Šojatski Dolac; Nada Prpić Terezina i Ivan Tomljanović Tole, Krivi Put; Ivica Vukelić Pop, Rupa, Ivan Vukelić Mikula, Cupići; Nikola Prpić Nikolčin, Francikovac; Pero Vukelić Mrco, Vukelići.

${ }_{107}$ Marko Pavelić Mijatin, Žuljevići; Pero Vukelić Mrco, Vukelići, Ivica Vukelić Pop, Rupa; Milan Tomljanović Periša, Zamalić.

${ }_{108}$ Milan Tomljanović Periša, Zamalić; Ivan Tomljanović Tole, Krivi Put.

109 Ivica Vukelić Pop, Rupa; Ivan Tomljanović Tole, Krivi Put.

110 Prema Ivici Vukeliću Popu iz Rupe.

111 Kako svi stanovnici ovog područja radi lakšeg sporazumijevanja imaju nadimke, tako je upravo majstorima koji su izrađivali samare pripisan nadimak Samardžija.

112 Ivica Vukelić Mikula, Cupići; Marija Prpić Nikolčina, Francikovac; Ivan Tomljanović Tole, Krivi Put. Ivan Tomljanović Tole prisjeća se da je jedan živio u Krivome Putu.

113 Prema Milanu Krmpotiću Zekonji iz Veljuna i Tomi Prpiću Marojici iz Mrzlog Dola.

114 Prema kazivanju Marka Pavelića Mijatine iz Žuljevića, Marka Tomljanovića Periše iz Zamalića, Tome Špalja Cucina iz Špalja, Peri Vukeliću Mrci iz Vukelića, Mariji Prpić Nikolčinoj iz Francikovca, Nadi Prpić Terezinoj i Ivanu Tomljanović Toli iz Krivoga Puta. 
pod kutom od $45^{\circ}$. Samar je sastavljen od drvenih letvi koje su spojene tako da dolaze na leđa magarcu i sa strane. Drveni dijelovi samara nazivali su se drvenina, dok ili trě̌anj. Prednji i stražnji kraj samara povezivao se letvama: sa svake strane stavljala se jedna letva, dok su gornji dio povezivala dva štapa čiji su vrhovi prolazili kroz prednju dasku samara, tj. glavić. Rogovi su najčešće izvirivali oko deset centimetara. ${ }^{115}$ Najčešće su se stavljale četiri potnice. ${ }^{116}$ Te letve nazivaju se potnice, odnosno, pričke. ${ }^{17}$ Potnice su najčešće široke pet centimetra. ${ }^{118} \mathrm{Na}$ rogove koji su virili naprijed vezao se konop, dok se drugi kraj konopa vezivao za križ. ${ }^{119}$ Često se upravo na križ ili rogove samara znala staviti torba ili nešto u čemu se

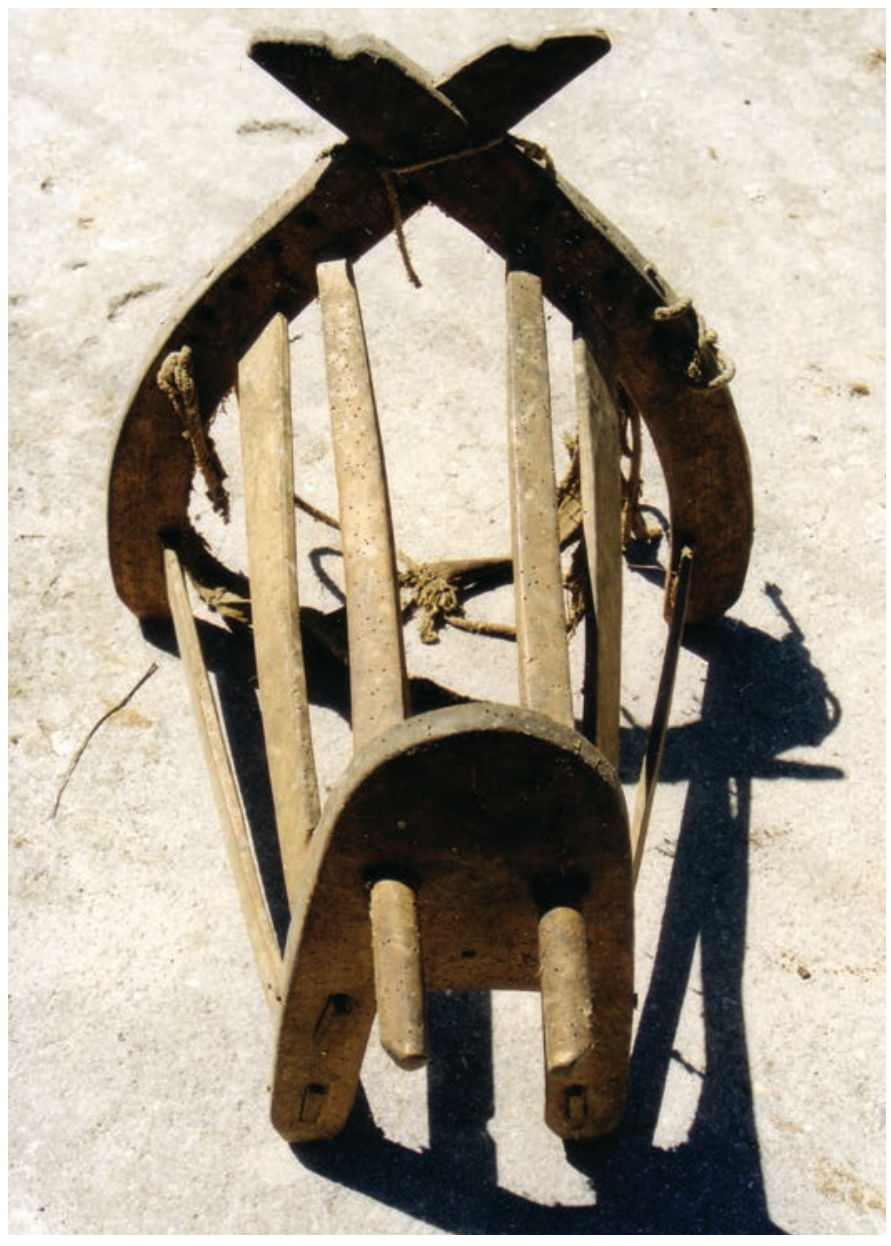

Slika 15: Samar, drvena konstrukcija, Cupici; snimio Augustin Peric, lipanj 2003. nosilo stvari. ${ }^{120}$ Takav samar imao je naziv dalmatinski samar. ${ }^{121} \mathrm{U}$ ovim krajevima najčešće se, prema kazivačima iz Zamalića i Špalja, koristio samar sa štapovima urezanim sa strane u daske samara. Nikola Prpić Nikolčin iz Francikovca navodi, međutim, da se kod njih koristio dalmatinski samar. Takav oblik samara ima bušene rupe u glaviću samara.

Svi kazivači navode da se ispod drvenoga dijela stavljala stelja napravljena od platna koje se gusto tkalo. Za tkanje platna koristila se konoplja, a platno se kupovalo u Lici jer u ovom kraju žene nisu tkale. Ivan Tomljanović Tole iz Krivoga Puta sjeća se da su često odlazili u Vratnik jer je tamo jedna žena tkala upravo platno za stelje. Kasnije se znala koristiti, a i danas, obična vreća koja se kupovala u trgovini. Bile su to vreće od jute. ${ }^{122}$ Unutar vreće stavljala se slama od zobi. ${ }^{123}$ I to tako da se ta slama nije vršila već su se samo otrgle klasi i za stelju koristila cijela slama. Stelja je obično bila debela šest do sedam centimetara. ${ }^{124}$ Slama se prošivala koncem od konoplje, drat ili dretva. ${ }^{125}$ Prošivalo se isključivo zbog toga da se slama unutar vreće ne pomiče. Igla koja se koristila za prošivanje bila je veća

15 Prema Ivanu Tomljanoviću Toli iz Krivoga Puta.

116 Prema kazivanju Ivana Tomljanovića Tole iz Krivoga Puta, Milana Krmpotića Zekonje iz Veljuna.

117 Prema kazivanju Tomi Špalju Cuci iz Špalja, Ivanu Tomljanoviću Toli iz Krivoga Puta, Ivanu Krmpotiću Šoparinu iz Šojatskog Dolca, Milanu Krmpotiću Zekonji i Luki Krmpotiću Brndi iz Veljuna.

118 Prema Ivanu Tomljanoviću Toli iz Krivoga Puta.

119 Prema Ivanu Vukeliću Mikuli iz Cupića, Milan Krmpotić Zekonja iz Veljuna i Ivan Tomljanović Tole iz Krivoga Puta.

120 Prema Nadi Prpić Terezinoj iz Krivoga Puta.

121 Prema kazivanju iz Rupa i Zamalića.

122 Milan Tomljanović Zekonja, Veljun.

${ }^{123}$ Prema Milanu Toljanoviću Periši iz Zamalića, Nadi Tomljanović Terezinoj i Ivanu Tomljanović Toli iz Krivoga Puta, Milanu Tomljanoviću Zekonji iz Veljuna te kazivačima iz Sojatskog Dolca, Špalja i Francikovca.

${ }^{124}$ Ivan Tomljanović Tole, Krivi Put.

125 Prema Ivanu Tomljanoviću Toli, Luki Krmpotiću Brndi i Milanu Tomljanoviću Zekonji iz Veljuna i Petru Šojatu Budiću iz Šojatskoga Dolca. 
i čvršća od obične igle i koristila se i za druge poslove. Stelja se kožnim konopcima vezala za drveni dio samara. ${ }^{126}$

Stelja je trebala zaštititi magarca, posebice ako je prevozio težak teret, a znalo se natovariti i do stotinu kilograma sijena. ${ }^{127} \mathrm{Na}$ mulu i konja, koji su jači od magarca, natovarilo se i do 120 ili čak 150 kilograma sijena ili drva kako navodi Milan Tomljanović Periša iz Zamalića. Krajevi samara pojačavali su se tako da se stavilo više slame, a to bi zvali pečenice. ${ }^{128}$

Uz drvene i platnene dijelove, samar je imao i dijelove napravljene od kupljenoga konopa. Konop je morao biti čvrst kako bi mogao izdržati teret. Na samar su se povezivala dva konopa na koje se stavljao teret. Ti su se konopi najčešće nazivali kolani, ali Ivica Vukelić Pop iz Rupe koristi naziv pomagače. ${ }^{129}$ Pojedini kazivači navode i naziv prače. ${ }^{130}$ Prilikom stavljanja tereta na samar pomoć je pružao drveni štap, sojica. ${ }^{131}$

Konop koji je dolazio ispod trbuha magarca nazivao se potpregalj, a onaj koji se stavljao ispod repa potpašaj. ${ }^{132}$ Prema kazivanju iz Žuljevića i Špalja te Francikovca nazivao se i pove. Svi su se ti konopci tkali od vune. ${ }^{133}$ Tkalo se debljine oprilike kao prst i dosta se nabijalo kako bi bilo čvrsto. To su radile žene, ali ne na tkalačkom stanu nego na škalama. ${ }^{134}$ Najčešće bi radile od crne i bijele pređe i od ostataka, dok se kasnije sve više počelo kupovati konope.

$\mathrm{Na}$ samaru su se na specifičan način vezale bale sijena za potrebe prevoženja. Trava za sijeno pokosila bi se prilično daleko od kuće, pa i na udaljenosti i do $10 \mathrm{~km}$. Za vezanje bala potrebno je imati tri konopa. ${ }^{135}$ Svaka bala zasebno se vezala jednim konopom dok je treći konop imao zadaću da poveže dvije bale dok se one stave na samar. Kada bi sijeno bilo dobro osušeno dva ili tri čovjeka su najčešće odlazila u polje po bale. Mogao je i sam čovjek ako je bio dosta spretan jer je balu tešku i do 50 kilograma trebalo smjestiti na samar.

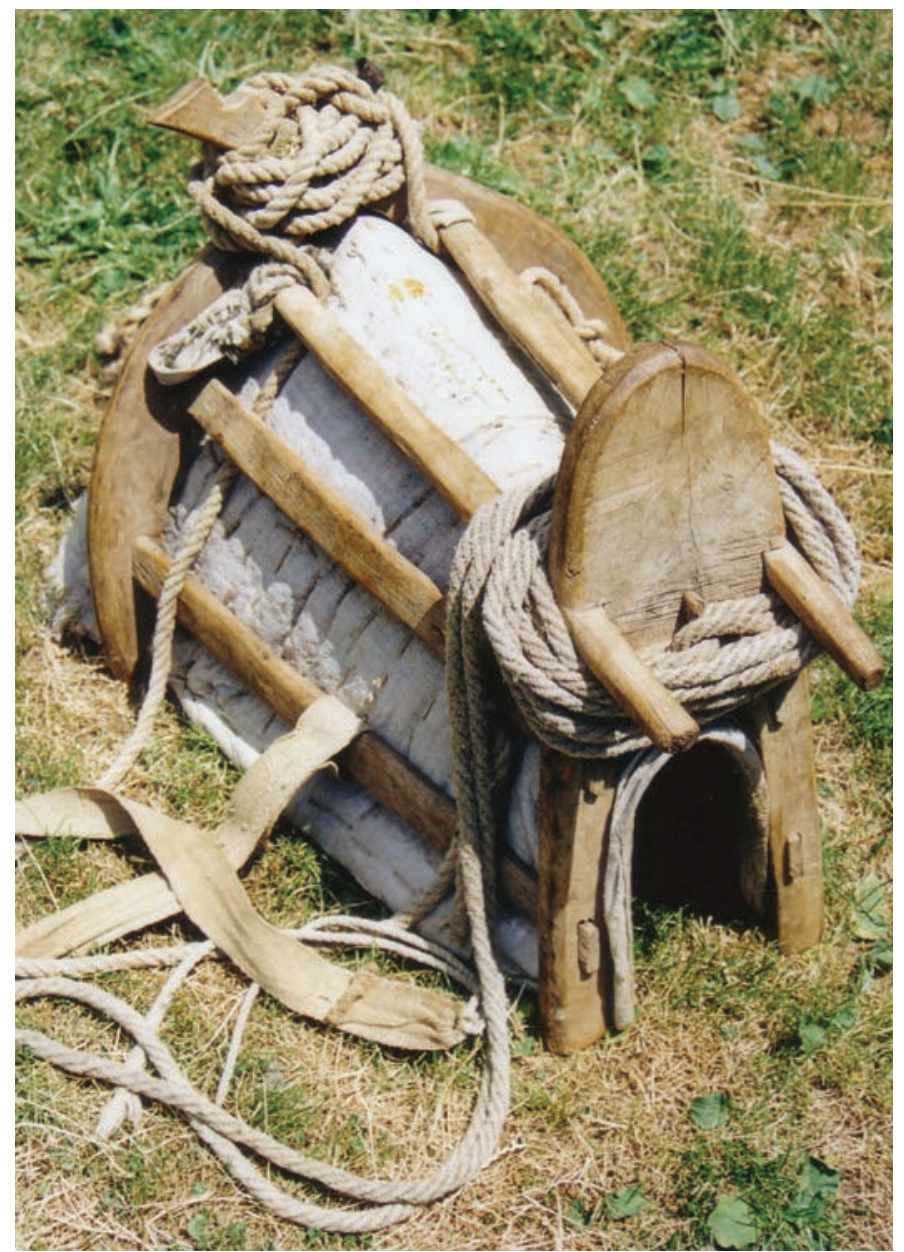

Slika 15a: Opremljen samar, Žuljevicí; snimila Jasmina Jurkovic, lipanj 2003.

\footnotetext{
126 Ivan Tomljanović Tole, Krivi Put.

127 Ivica Vukelić Pop, Rupa.

128 Prema kazivanju iz Špalja, Francikovca, Rupe i Ivanu Tomljanoviću Toli iz Krivoga Puta te Luki Krmpotiću Brndi iz Veljuna.

${ }^{129}$ Milan Tomljanović Periša, Zamalić; Tomo Špalj, Cucin, Špalji.

130 Kazivač Marko Tomljanović Kanada iz Žuljevića, Ivan Tomljanović Tole iz Krivoga Puta i Tome Špalj Cucin, Špalji.

131 Ivan Tomljanović Tole, Krivi Put; Ivan Krmpotić Šoparinu, Šojatski Dolac.

132 Ivica Vukelić Pop, Rupa.

133 Tome Špalja Cucin, Špalji; Marija Prpić Nikolčina, Francikovac.

134 Stepenice.

135 Prema Ivici Vukeliću Popu iz Rupa; kazivanju iz Zamalića, Cupića, Žuljevića, Alana. Konop - prema kazivanju iz Žuljevića.
} 
Sijeno bi se slupilo ${ }^{136}$ (položilo) na hrpu, prije toga trebalo je konop složiti na zemlji i onda na to stavljati sijeno. Kada se vezala bala konopi su se ispreplitali oko nje. Obično su je vezala dva čovjeka jer je tako bilo lakše (svezana bala može se usporediti s paketom). Kad se bale svežu na zemlji i malo očešljaju trebalo ih je staviti na samar. Prva bala koja se stavljala na samar zvala se sukana bala koja nije imala krajeve konopa vani, a druga dizana bala, prema Ivici Vukeliću Рори iz Rupe i kazivanju iz Francikovca. Pri stavljanju bala na samar važnu ulogu imao je procip (sl. 16). ${ }^{137}$ Procip je straga imao rašlju i tu bi se svezao konop oko te rašlje dok je naprijed bio ušiljena oblika. ${ }^{138}$ Pomoću procipa provlačio se treći konac kroz bale. Kada se konop provukao kroz bale između bi stavljali životinju. Tada bi se dizala prva bala koja nije imala krajeve konopa vani i ona bi se držala na konopima. Konopi su se učvršćivali i za prednji dio samara gdje su bili

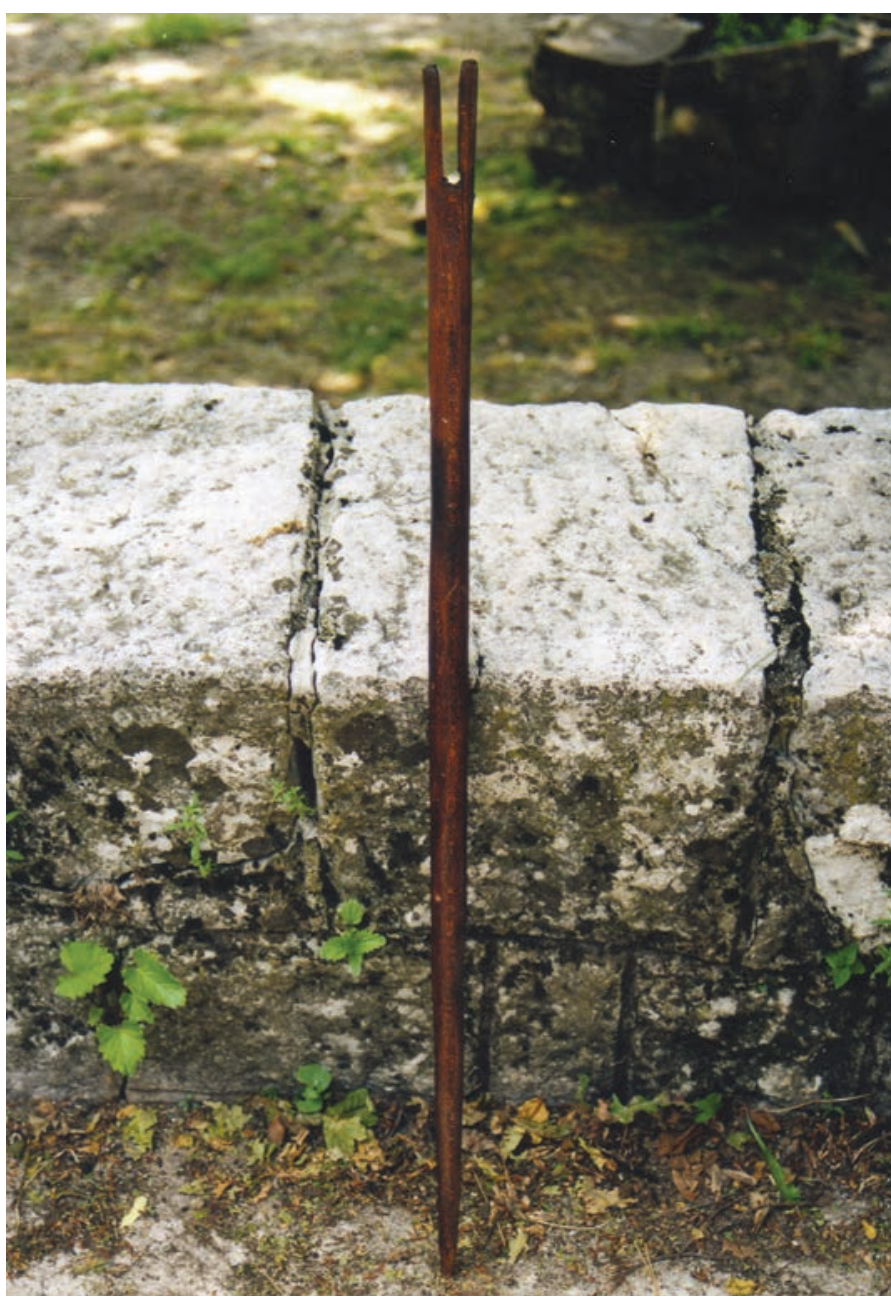

Slika 16: Procip, Cupići; snimio Augustin Perić, lipanj 2003. rogovi i za stražnji dio gdje je bio križ. Tada bi dizali drugu balu i to pomoću konopa. Zatim su se konopi prebacili i vezalo se na onoj strani gdje je bila dizana bala.

Konop koji se koristio najčešće se kupovao u trgovinama. Kada se kupovalo znalo se točno koliko metara treba za vezanje određene bale. ${ }^{139}$ Najčešća dužina konopa je oko 5-6 metara.

Osim sijena, ljudi su na samarima prevozili drva, gnojivo, ali i namirnice koje su znali voziti na prodaju u Senj. Gnojivo su morali stavljati u vreće i tako prevoziti na polje. ${ }^{140}$ Dosta slično prevozio se krumpir. Drva su prevozili tako da su ih vezali konopom, a zatim su konope vezali na samar na križ i glavu (sl. 17). ${ }^{141}$

Žene su najčešće na samarima na mulama prevozile drva na prodaju u Senj, a vraćale se sa solju, brašnom, kavom i šećerom. ${ }^{142}$ Prema Podbilu, Šimerićima, Žuljevićima, Špaljima, Francikovcu žene su vozile i mlijeko, sir, jaja i maslac, a kupovale su kukuruzno brašno i duhan.

U Senj su većinom, pa gotovo isključivo, odlazile žene koje bi prodavale drva, mlijeko, sir i vlastite domaće proizvode. ${ }^{143}$

${ }^{136}$ Ivica Vukelić Pop iz Rupa.

137 Komad drveta oblikovan kao igla.

138 Prema kazivanju iz Francikovca.

139 Prema kazivanju iz Zamalića i Žuljevića.

${ }^{140}$ Ivan Vukelić Mikula, Cupići.

${ }_{141}$ Ivica Vukelić Pop, Rupa i kazivanje iz Zamalića.

${ }_{142}$ Prema Ivanu Vukeliću Mikuli iz Cupića, kazivanju iz Podbila, Špalja i Žuljevića.

${ }_{143}$ Marija Tomljanović Čonina, Podbilo; Gašpar Butković Rila, Alan; Tome Špalj Cucin, Špalji; Marko Pavelić Mijatin, Žuljevići; Ivan Vukelić Mikula, Cupići. 
Taj put dug je gotovo 8 kilometara, a žene su ga prelazile pješice, dok je konj ili magarac prenosio teret. ${ }^{144}$ Tržnica se nalazila u središtu grada, tamo se zvalo jedan dio aleji to je šetalište pa sa desne strane ima voda tri pipe i korito tu su vezali magarce da se napoje i onda su ovi mulci (klinci) po Senju jašili. ${ }^{145}$ Iz sela koja su bila bliže gradu, primjerice Klarićevac, žene su nosile mliječne proizvode, dok su iz onih sela koja su se nalazila dalje vozili drva. ${ }^{146}$ Obično su žene već imale svoje stalne kupce, konte, pa bi nakon prodaje odlazile u nabavku namirnica za svoje domaćinstvo. ${ }^{147}$ Tomo Špalj Cucin iz Špalja prisjeća se kako su osim kućnih potrepština žene kupovale muškim ukućanima duhan, čak bi se, ako je koji puta i zaboravila, morala vratiti bez obzira na dug put ili loše vrijeme. Često puta bi se građani Senja ljutili kada bi žene dolazile kolima u grad jer bi željezni kotači jako bučili na asfaltu. ${ }^{148}$ Obično bi pogrdno gledali na to premda su donekle ovisili o Bunjevkama i njihovim proizvodima. Kada su šezdesetih godina došli gumeni kotači situacija se donekle u tom smislu poboljšala. Ivan Vukelić Mikula iz Cupića sjeća se kako je njegova baka vozila drva na prodaju u Senj, ja sam je čekao, znala je da donese iz Senja bajsicu, to je kruh malo posut cukorom i ja to pojedi ko med.

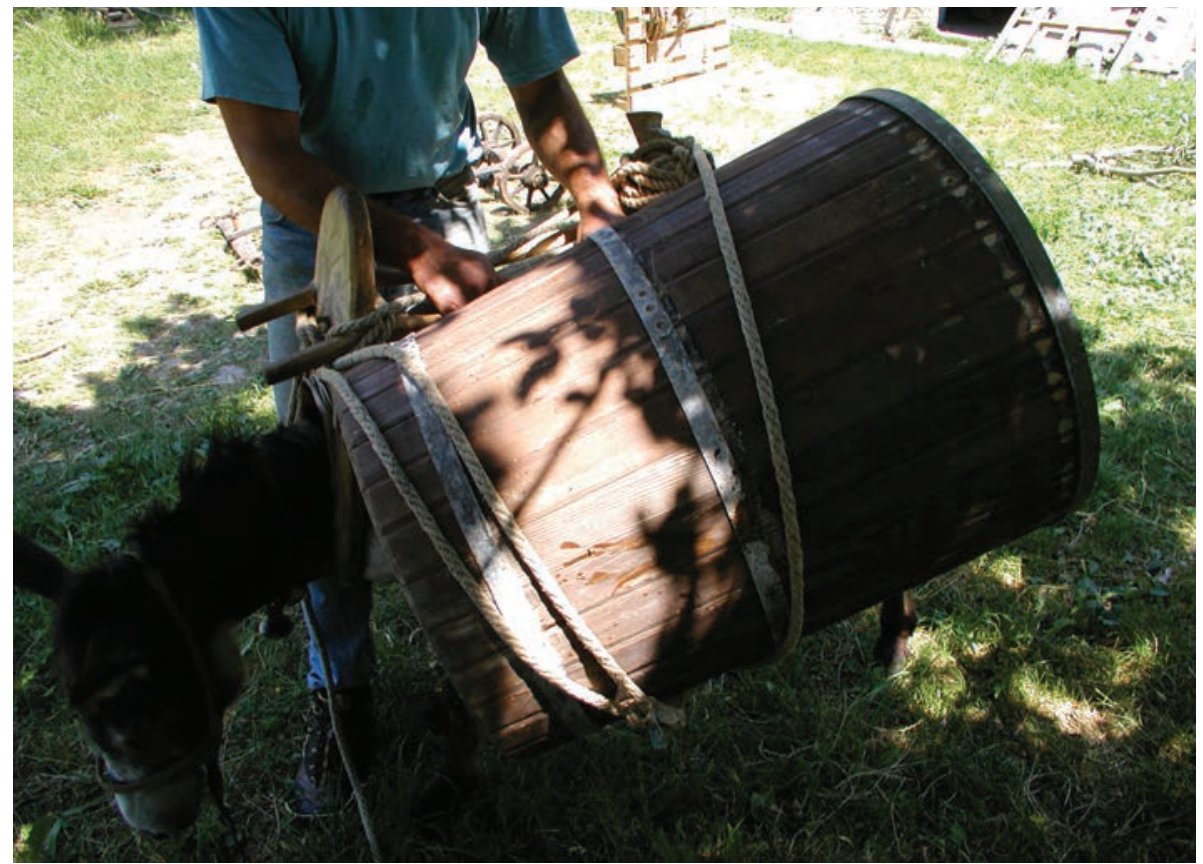

Slika 17: Stavljanje tereta na samar, Žuljevicí; snimila Danijela Birt, lipanj 2003.

144 Tome Špalj Cucin iz Špalja. Isti kazivač ispričao je tužnu priču kako su se jedne zime 1897. godine, kako je tu bio običaj da se za Badnjak jede bakalar, njegova baka i od dva brata žene i kćer, sve iz iste kuće uputile u Senj. Nažalost, uhvatila ih je vijavica te su se izgubile i smrznule. Kazivač se sjetio i još jedne zgode, ali koja je donekle poprimila šaljivu notu. Jedan je čovjek, također u božićno vrijeme, išao u Senj, ali po nagovoru svećenika kome su trebale neke stvari. Nažalost, čovjek je stradao, ali iz svega toga rodila se pjesma: pogine stari za popove stvari, di pogine krštan za popov brštan.

145 Marko Tomljanović Cote, Šimerići.

146 Tome Špalj Cucin, Špalji; Gašpar Butković Rila, Alan; Marko Pavelić Mijatin, Žuljevići; Marko Tomljanović Cote, Šimerići; Ivan Vukelić Mikula, Cupići.

147 Pogledaj poglavlje o mljekaricama i trgovini drvima u prilogu o trgovini i sajmovima u ovoj monografiji.

148 Marko Tomljanović Cote, Šimerići. 


\section{IZVOR:}

Upitnice Etnološkogg atlasa (UEA), Mjesto (selo) Krivi Put (signatura Fd 241), svezak III., teme: 100. Jaram; 101. Konjska oprema; 102. Kola za rad, saone, vlačuga; Arhiv Odsjeka za etnologiju i kulturnu antropologiju, Filozofski fakultet u Zagrebu. 